University of Louisville

ThinkIR: The University of Louisville's Institutional Repository

Electronic Theses and Dissertations

$5-2013$

\title{
Unconventional warfare in the Ottoman Empire : Turkish counterinsurgency and their Western inspiration.
}

Nicholas A. Warndorf 1987-

University of Louisville

Follow this and additional works at: https://ir.library.louisville.edu/etd

\section{Recommended Citation}

Warndorf, Nicholas A. 1987-, "Unconventional warfare in the Ottoman Empire : Turkish counterinsurgency and their Western inspiration." (2013). Electronic Theses and Dissertations. Paper 1532.

https://doi.org/10.18297/etd/1532

This Master's Thesis is brought to you for free and open access by ThinkIR: The University of Louisville's Institutional Repository. It has been accepted for inclusion in Electronic Theses and Dissertations by an authorized administrator of ThinkIR: The University of Louisville's Institutional Repository. This title appears here courtesy of the author, who has retained all other copyrights. For more information, please contact thinkir@louisville.edu. 


\title{
UNCONVENTIONAL WARFARE IN THE OTTOMAN EMPIRE
}

\author{
Turkish Counterinsurgency and Their Western Inspiration
}

By

Nicholas A. Warndorf

B.A. Northern Kentucky University, 2011

\begin{abstract}
A Thesis
Submitted to the faculty of the

College of Arts and Sciences of the University of Louisville in partial fulfillment of the Requirements

for the Degree of
\end{abstract}

Master of Arts

Department of History

University of Louisville

Louisville, Kentucky

May 2013 
Copyright 2013 by Nicholas A. Warndorf

All rights reserved 


\section{UNCONVENTIONAL WARFARE IN THE OTTOMAN EMPIRE}

Turkish Counterinsurgency and their Western Inspiration

\section{By}

Nicholas A. Warndorf

B.A., Northern Kentucky University, 2011

A Thesis Approved on

April 19, 2013

By the following Thesis Committee:

Br. Justin McCarthy (Thesis Difector)

Dr. Daniel Krebs

Dr. Julie Peteet 


\section{DEDICATION}

This thesis is dedicated to my brother

\section{Christopher Tyler Warndorf}

who provided me the conviction, fortitude, and comparative character to succeed in academia as well as many other aspects of my life through his service and his sacrifice for our country. 


\section{ACKNOWLEDGMENTS}

I would like to thank my Thesis advisor, Dr. Justin McCarthy, for his guidance and inspiring demeanor which led me through what has been a rewarding struggle. I would also like to thank the other committee members, Dr. Daniel Krebs and Dr. Julie Peteet, for their time, patience and guidance in my writing and revision. I would like to express my thanks to Professor Terence Fleming, Dr. Robert Wilcox, Dr. William Landon and Dr. Clyde Booker for all their assistance and influence in my undergraduate studies, which helped me get to where I am now. I would like to thank my close friend and mentor Charles Snow who has been like a father to me and my close friends Roger and Martha Bell, all of which have been influential in shaping my understanding of the world from a great many different perspectives. I would like to thank my sister Katelyn Warndorf, who is the light in my life when all other lights are fading, reminding me that

perseverance does not go unnoticed. Finally, I would like to thank my good friend Nikki Deese for all of her help and support through the most difficult phase of this arduous but fulfilling process. 


\begin{abstract}
UNCONVENTIONAL WARFARE IN THE OTTOMAN EMPIRE TURKISH COUNTERINSURGENCY AND THEIR WESTERN INSPIRATION

Nicholas A. Warndorf
\end{abstract}

April 19, 2013

This thesis examines the counterinsurgency efforts of the Ottoman Empire during the First World War and the evolutionary process through which those techniques were created. The importance of this is to demonstrate the ever changing nature of warfare as well as the adaptability a counterinsurgent requires. It also demonstrates how the West practiced counterinsurgency techniques over a decade before the First World War and that those techniques often led to civilian suffering. By comparing the British and American experiences with insurgency in South Africa and the Philippines, this thesis shows that population control is one of the most effective counterinsurgency techniques. This assertion is based on research of previous counterinsurgents as well as Western doctrine. This thesis provides evidence that the Ottoman decision to deport large numbers of Armenians was a decision made out of necessity, and considered the most effective counterinsurgency technique in the midst of World War I. 
TABLE OF CONTENTS

PAGE

ACKNOWLEDGEMENTS .......................................................

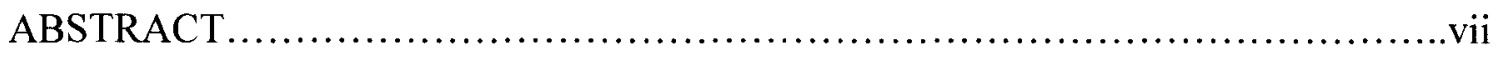

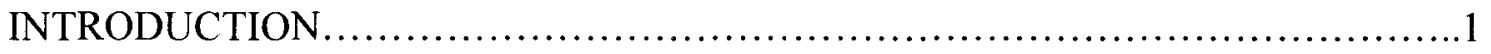

HISTORIOGRAPHY AND METHODOLOGY ...................................

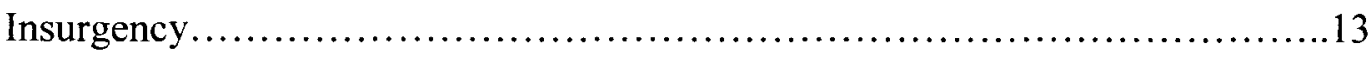

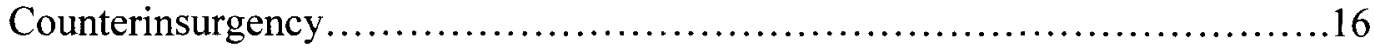

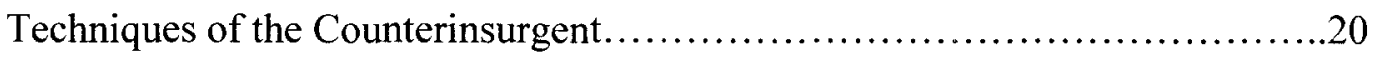

OTTOMAN COUNTERINSURGENCY AND THE REBELLION AT

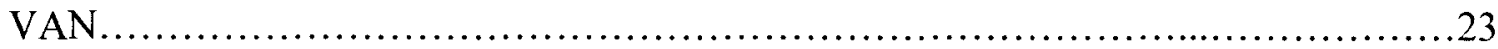

The Ottoman Military and Popular Mythology .................................24

Formation of the Ottoman Military and the Situation in the East.................27

Ottoman Counterinsurgency Heritage........................................32

Preparations for War and the Threat of an Armenian Fifth Column...............38

Border Security and Armenian Operations..................................41

The Van Insurgency and the Ottoman Response..............................51

THE WESTERN WORLD AND THE COUNTERINSRUGENCY EXPERIENCE

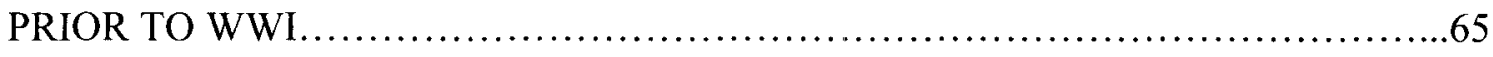

British South Africa and the Anglo-Boer War...............................65 


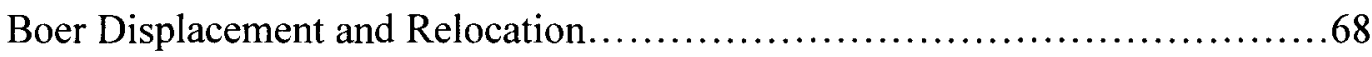

South East Asia and the Philippine-American Conflict..........................75

Filipino Displacement and Relocation........................................77

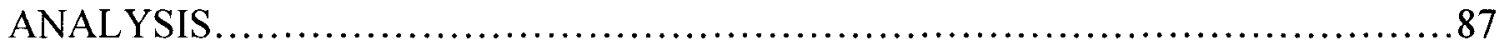

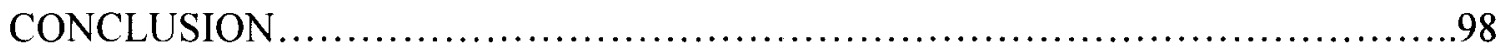

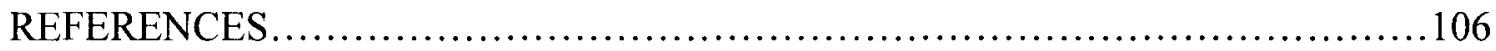

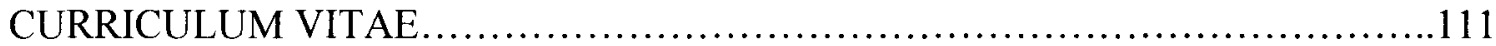




\section{SPELLING AND PRONUNCIATION}

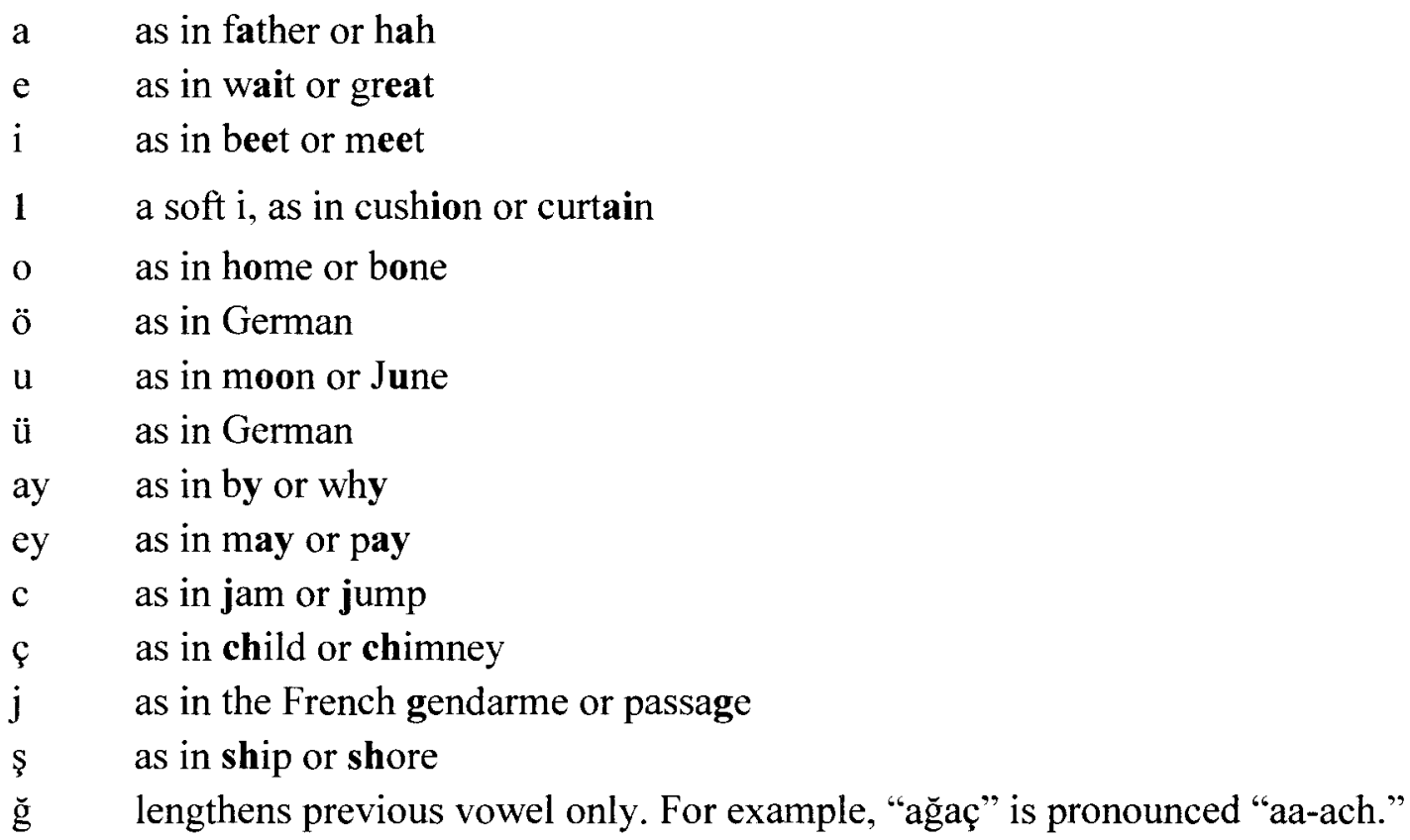




\section{CHAPTER I}

\section{INTRODUCTION}

"Counterinsurgency is an old issue with new currency in the twenty-first century... Counterinsurgency is an issue area where there are many scholarpractitioners (in contrast to other areas of security studies) which gives their writings a certain immediacy and applicability. Many of these scholarpractitioners are engaged in trying to change the way the militaries understand and fight these 'hearts and minds' campaigns."

Joanna Spear, Security Studies, 2008

The purpose of this thesis is to assess the Ottoman military application of counterinsurgency in Eastern Anatolia during the First World War. It argues that by isolating and or removing civilian populations from areas of unrest and rebellion, the Ottoman government was able to quell insurgencies, with particular attention given to a rebellion in the city of Van. Historically, the Ottoman Empire has been misrepresented in the West to the point of only basic recognition. To the average observer, mention of the Ottomans or the Turks can either generate discontent and preconceived notions of barbarity or a kind of adolescent admiration for the exotic though it is not fully understood. This is mainly because the Ottoman Empire's reputation has been so diluted by past Western observers that their history, especially their military, is riddled with such condemnation that the truth has nearly become indecipherable. It is necessary to examine the great civilizations of the past with an open mind and without prejudice if we are to better understand the present and hopefully prepare for the future.

\footnotetext{
1 Joanna Spear, "Counterinsurgency," in Security Studies: An Introduction, ed. Paul D. Williams,
} (New York: Taylor \& Francis, 2008), 389. 
The nature of warfare has always and will continue to be a process of evolutionary thought in overcoming one's enemies. Contrary to popular belief of the uninitiated, warfare is far more complicated than the number of men and the type of equipment that is used. It is by definition "a conflict carried on by force of arms, as between nations or between parties within a nation."2 The nature of such conflicts can take a number of different forms. Most widely recognized, of course, is large scale conflict that occurs between nations. Warfare, though, is not always the product of disagreements among giants. In many cases throughout history, it has been an outlet for emerging groups or minorities within a nation in an attempt to throw off the repressive yolk of a larger, more powerful opponent.

The opponent can be an invader or the governmental structure of one's own nation. Governments have an inherent need to control their population, whether it be for reasons of utilitarian good, striving for the most agreeable living conditions in the minds of the masses, or as an attempt to repress and control the masses for the benefit of a few. The answer for the minority has often been that of the protracted or prolonged "small war," also known as the guerrilla war or insurgency. Such warfare is perhaps the greatest enemy to the continuity of a nation because it is a conflict bred from within. Therefore, in an effort to combat such threats, nations are forced to adapt and invent new measures in order to overcome an almost invisible force which gains momentum with every small victory. The United States Department of the Navy and the Marine Corps define such tactics in their Small Wars Manual:

\footnotetext{
2 "War," last modified December 10, 2012, http://dictionary.reference.com/browse/war
} 
As applied to the United States, small wars are operations undertaken under executive authority, wherein military force combined with diplomatic pressure in the internal or external affairs of another state whose government is unstable, inadequate unsatisfactory for the preservation of life and of such interests as are determined by the foreign policy of a nation. ${ }^{3}$

Although the Small Wars Manual was published in 1940, it is one of the first doctrinal manuals published on the subject. References to various western manuals throughout the twentieth century illuminate the evolution of military thought, as well as an effort to combat the changing nature of warfare.

Vilification of the Ottoman military in historical adaptations has led to the belief among many scholars that during the First World War, the Ottoman Empire had made a conscious effort to eradicate rural populations of Armenians in Eastern Anatolia. Upon further scrutiny, however, it becomes apparent that the Ottomans felt they must act, fearing the potential threat of a Russian invasion by developing a fifth column ${ }^{4}$ insurgency using discontented Anatolian Armenians. This thesis argues that the Ottoman counterinsurgency efforts were bred of a perceived necessity and not a targeted aggression toward any specific religious or ethnic group. By comparing counterinsurgency efforts of the Ottomans to those of the Americans in the Philippines and the British approach in South Africa, this thesis demonstrates that the Ottomans were merely adapting contemporary counterinsurgency measures which had already been used before by their Western counterparts. Such efforts mainly focused on the use of forced

\footnotetext{
${ }^{3}$ Department of the Navy and the USMC, Small Wars Manual (Washington: United States Government Printing Office, 1940), sect. 1-1 p. 1

${ }^{4}$ The term "Fifth Column" was first applied in 1936 to rebel sympathizers inside Madrid when four columns of rebel troops were attacking that city. The term is defined as "a clandestine subversive organization working within a given country to further an invading enemy's military and political aims. (see The American Heritage Dictionary, [Boston: Houghton Mifflin Company, 1982], "fifth column".)
} 
relocations and civilian re-concentration. One only has to examine modern examples such as Sri Lanka in order to grasp the concept.

The Ottoman soldier was among the most courageous, obedient and steadfast of battle implements to have ever been applied to warfare. Their bravery alone was enough to merit recognition that would resonate in the pages of history. Unfortunately, this is often distorted in the twenty first century. Among the many scholars of the Middle East, only a few recognize the inadequacies of past research and manage to give credit where it is due regarding Muslim soldiers. Illusive histories and subjective recollections from the winning side of World War I have often been the source by which all others follow. This thesis sheds light on at least one element of Ottoman military conduct during the First World War that is still widely and sometimes veraciously debated today.

A primary argument that this thesis also makes is that the nature of insurgency demands a level of adaptation and evolution that is often difficult to understand for those unfamiliar with irregular warfare. The approach to insurgency by Western empires differed little from the approaches used by the Ottoman Empire to secure areas of contention through the isolation of civilian populations. None has proven more influential or controversial than the calculated use of concentration camps and relocation. This is evident in the examination of the American application in the Spanish-American War of 1898, the Philippine-American war of 1899-1902, and the British use of concentration camps during the Second Boer War of 1899-1902. Each conflict predates the First World War and remains an example of Western technique ${ }^{5}$ which the Ottomans later used.

\footnotetext{
${ }^{5}$ Technique is the appropriate word to use because the concept of a standardized doctrine in counterinsurgency operations was not effectively developed until after World War II. Therefore, for the purposes of this paper, I have chosen to use the word "technique" in order to refer to western and Ottoman counterinsurgency measures rather than "doctrine," which is the accepted designation today.
} 
Based on historical evidence and the insights of contemporary Middle Eastern military scholars, the Ottoman response was not only appropriate but viewed as ultimately necessary, in the context of the time, to insure the continuity of the Empire. Faced with heavy Russian opposition and the threat of a potential fifth column from the Ottoman Armenian Christians of Eastern Anatolia, the Ottoman Empire responded to internal threats in a way intended to save their Muslim subjects that were dying by the millions, while also repelling a Russian invasion during World War I.

The threat of insurgency is not a new concept. However, the need to combat unconventional warfare while maintaining political integrity abroad has become a growing concern for virtually every emerging super power of the last three hundred years. With regard to quelling rebellion and fighting an enemy within, few nations have received more consistent scrutiny than the Turks. Wartime propaganda and sensationalism of the Western press during World War I has persisted even today, calling the Ottoman response to internal security threats "genocide" and "massacre" of innocent civilians. ${ }^{6}$ The reality, however, is that Armenian rebels who were willing to utilize murder, kidnapping, public executions, propaganda, smuggling, bombings, and desertion from the Ottoman military - virtually anything that would weaken the Turks - often goes unmentioned.

Genocide is not a valid accusation when examining this period of Ottoman history. By definition, the word means "The systematic, planned annihilation of a racial, political, or cultural group." "Modern scholars of the subject often point to the Turkish relocation of Armenians during the war as the definitive moment that marked their

6 “Armenian Genocide," last modified April 16, 2012, http://www.unitedhumanrights.org/genocide/armenian_genocide.html

${ }^{7}$ The American Heritage Dictionary, (Boston: Houghton Mifflin Company, 1982), "Genocide" 
planned annihilation. History has proven, however, that the West has a short memory with regard to insurgency techniques. The relocation of perceived combatants has been common with regard to national security in Western military practice both before and since World War I, with the use of internment by the British during the Second Boer War and also by the United States during World War II with the internment of Japanese Americans following the attack on Pearl Harbor. The Ottoman military showed remarkable restraint in times of great emotional turmoil regarding relocation and securing areas under insurgent control. Recent research has also shown that according to Ottoman records, Turkish military conduct was often the equivalent, if not superior, to Western military conduct when fighting an unconventional war.

The study of irregular or unconventional warfare during the First World War is essential if both scholars and practitioners are to better understand the changing nature of twenty-first century conflict with any nation, against any enemy, both foreign and domestic. Karl Von Clausewitz, soldier and military theorist wrote that "Theory exists so that one need not start afresh each time sorting out the material and ploughing [sic] through it, but will find it ready to hand and in good order. It is meant to educate the mind of the future commander, or, more accurately, to guide him in his self-education, not accompany him to the battlefield. ${ }^{\prime 8}$ Contemplation and adaptation are not enough if one does not recognize the successes and failures of past engagements, wherever and whenever they may have occurred.

Contemporary military doctrine of the West and tested attempts at subduing civilian populations are proof enough that although such methods continue to receive

\footnotetext{
${ }^{8}$ David Lonsdale, "Strategy," in Understanding Modern Warfare, ed. David Lonsdale et al. (New York: Cambridge University Press, 2008), 20.
} 
condemnation, they are nevertheless continually applied to combat unconventional warfare. The difference between the early twentieth century and present counterinsurgency measures is that there is heavier focus today on a more humanitarian solution. By the comparison of Ottoman techniques to their Western precursors, this thesis argues that their methods were learned and adapted, not invented. That is why I have chosen to focus heavily on the formation of the Ottoman military and how their own experiences in the Balkans helped to shape their approach to Eastern Anatolia. It is also why I have chosen to compare those methods to the current military doctrine of the United States, as well as the practices of both the British and Americans prior to World War I. Their experiences highlight the reality that sometimes, the focus on achieving victory can overshadow the concern for reducing collateral damage. They also prove that in over one hundred years, controlling the population is still the paramount concern in unconventional warfare. 


\section{CHAPTER II}

\section{HISTORIOGRAPHY AND METHODOLOGY}

Among the many problems with research on the First World War and Ottoman approaches to irregular warfare are the glaring gaps in research on the subject. Definitions of insurgency and counterinsurgency are often too vague or contradictory, if they are even mentioned at all. Ottoman relocations and civilian concentration is roundly criticized as genocide and calculated pogroms against the Armenian people. Yet, at the same time, western recollections of past engagements using the same methods are referred to as re-concentration in the Spanish American war and the Philippines, Internment camps during WWII, strategic hamlets in Vietnam ${ }^{9}$, and camps in South Africa during the Second Boer War. Regardless of one's position on the subject, it is undeniable that civilian non-combatants generally pay the greatest price in war. Regarding insurgencies, however, knowing the difference between combatant and noncombatant becomes incredibly difficult.

For this reason, I have taken a three pronged approach to my argument regarding methodology and sources. First, I explain the evolution of Ottoman military strategy and how their experiences in the Balkans and military restructuring led to their counterinsurgency techniques used in the First World War. This section focuses heavily on the rebellion at Van and how the Armenian struggle against the Ottoman government

${ }^{9}$ Thomas L. Ahern Jr., Vietnam Declassified: The CIA and Counterinsurgency, (Lexington: The University Press of Kentucky, 2010), 76-78. 
can be classified as an insurgency. By focusing on the Ottomans first and their military tactics prior to and during World War I, it is my argument that the empire mainly acted in the interest of self preservation and not out of religious or ethnic hatred regarding the Armenians of eastern Anatolia.

Secondly, in order to encompass theory and practice, that is, what is written by scholars and how applicable such theories are on the ground, I have decided to utilize both scholarly examinations of previous conflicts for their historical context as well as doctrinal practice in western military manuals on counterinsurgency. Accompanying the scholarly interpretations of irregular warfare, I have also chosen to apply the writings of both insurgents and counterinsurgents such as Mao Tse-tung, Che Guevara, and T.E. Lawrence among others. These two different perspectives are referenced throughout my thesis but are mainly used regarding the application of concentration and relocation by Great Britain and America. Focusing on each country's respective conflicts and their own experiences with insurgency abroad provides a framework for comparing how two western empires conducted counterinsurgency prior to the Ottomans.

The third aspect of my research is an analysis of the western approach versus the Ottoman approach to counterinsurgency, highlighting their similarities and their differences. Pointing to both western adaptations of war and Ottoman adaptations paints a more accurate picture regarding the fickle nature of historical representation. By using such methods, this thesis asserts that through the comparison and contrast of Ottoman counterinsurgency techniques of the First World War to their western precursors the research reflects that Ottoman methods were learned and adapted, not invented. It is also 
intended to demonstrate that the nature of irregular warfare demands drastic measures from any nation.

In studying the art of unconventional warfare, it is essential to consult the expertise of previous practitioners. Irregular war can be traced back to the Old Testament in the first and second books of Maccabee. The stories describe the Jewish family of Maccabeus' guerrilla campaign of irregular warfare against their Syrian oppressors, led by Judas Maccabeus. The stories tell of their insurgent efforts which ended in a treaty with the Syrians in $158 \mathrm{BCE} .{ }^{10}$ Perhaps the most recognizable figure in the nature of warfare with special emphasis on irregular tactics, however, dates back to fifth century China and writings in Sun Tzu's The Art of War. The book is a collection of writings by Chinese military strategists written for the sole purpose of attaining victory and overcoming one's enemies, both on and off the battlefield. The significance of these references is the recognition that not only is the concept of irregular warfare an ancient contemplation, it is also evolving with every new generation of soldier and the implements of war that he or she uses. On the use of military force, Sun Tzu writes:

The military is a Tao of deception - Thus when able, manifest inability. When active, manifest inactivity. When near, manifest as far. When far, manifest as near. Thus when he seeks advantage, lure him. When he is in chaos, take him. When he is substantial, prepare against him. When he is strong, avoid him. When he is wrathful, harass him. Attack where he is unprepared. Emerge where he does not expect it."

In hindsight the concept seems simple enough. It is important to remember, however, that such notions of warfare can apply to the offensive and defensive movements of both a larger and smaller force. The West has dealt with a number of

\footnotetext{
${ }^{10}$ Ian F. W. Beckett, Modern Insurgencies and Counter-Insurgencies: Guerillas and their opponents since 1750 (London: Routledge, 2001), 1

"Sun Tzu, The Art of War trans. The Denma Translation Group (Boston: Shambhala Publications Inc., 2002), 5 .
} 
instances in a number of theaters where numbers do not always count for everything. This is evident throughout the colonial expansion period of western empires abroad and continued into the island fighting of the Pacific during World War II. It is even more prevalent in the twenty-first century with coalition forces' efforts in Afghanistan and Iraq.

Many scholarly sources point to a number of different aspects that must be considered when fighting an unconventional war. Definitions of warfare, of which there are many, can often be misleading and malleable to virtually any situation. David Lonsdale, Professor from the Department of Politics and International Studies at the University of Hull argues that, "Definitions (of war) that focus simply on body count are simplistic to the point of absurdity, ignoring the political and legal implications of defining war, in addition to saying nothing about the actual conduct of military operations." ${ }^{12}$ Therefore, for the purposes of this thesis, it is essential to narrow down the varying degrees of warfare and how it applies to the Ottomans by focusing on what types of irregular warfare exist. James Kiras, Professor at Air University of the United States Air Force from the School of Advanced Air and Space Studies, has argued that there are in fact five forms of irregular warfare which are adequately described in this table from a book he coauthored titled Understanding Modern Warfare.

\footnotetext{
${ }^{12}$ Lonsdale, "Strategy," 1.
} 
Table 2.1 Forms of Irregular Warfare ${ }^{13}$

\begin{tabular}{|l|l|l|l|l|l|l|}
\hline Type & Resources & $\begin{array}{l}\text { Center of } \\
\text { Gravity }\end{array}$ & Mechanism & $\begin{array}{l}\text { Strategic } \\
\text { Orientation }\end{array}$ & $\begin{array}{l}\text { Tactical } \\
\text { Orientation }\end{array}$ & Duration \\
\hline Coup d'état & Few & $\begin{array}{l}\text { Elites } \\
\text { (organize) }\end{array}$ & $\begin{array}{l}\text { Seizure of } \\
\text { power }\end{array}$ & Offensive & Offensive & Immediate \\
\hline Terrorism & Few & $\begin{array}{l}\text { Elites } \\
\text { (influence) }\end{array}$ & Coercion & Offensive & Offensive & Lengthy \\
\hline Revolution & $\begin{array}{l}\text { Vanguard, } \\
\text { growing to } \\
\text { many }\end{array}$ & $\begin{array}{l}\text { Population } \\
\text { (Stimulate) }\end{array}$ & $\begin{array}{l}\text { Popular } \\
\text { support } \\
\text { (uprising) }\end{array}$ & Defensive & Offensive & $\begin{array}{l}\text { As quickly } \\
\text { as possible }\end{array}$ \\
\hline Insurgency & $\begin{array}{l}\text { Varied, but } \\
\text { significant }\end{array}$ & $\begin{array}{l}\text { Population } \\
\text { (Control) }\end{array}$ & $\begin{array}{l}\text { Denial } \\
\text { leading to } \\
\text { victory over } \\
\text { or } \\
\text { withdrawal } \\
\text { of opponent }\end{array}$ & $\begin{array}{l}\text { Defensive, } \\
\text { switching to } \\
\text { offensive }\end{array}$ & $\begin{array}{l}\text { Offensive, } \\
\text { given local } \\
\text { superiority }\end{array}$ & Lengthy \\
\hline Civil War & Varies & Varies & $\begin{array}{l}\text { Denial or } \\
\text { negotiated } \\
\text { settlement }\end{array}$ & Varies & Varies & Varies \\
\hline
\end{tabular}

It is necessary to examine the meaning of insurgency and counterinsurgency from a variety of sources in order to better understand the complexities of unconventional warfare. By defining the two and their application in past and present military conflicts, it is my intention to clarify such encompassing concepts to better direct the reader toward a clear understanding of the topic. It would be unwise to focus on all forms of irregular warfare because the scope of such a topic exceeds the capacity of this thesis. It is also necessary to recognize the importance of the "center of gravity" distinction in defining forms of warfare. Though the specific class of society is subject to change with the type of warfare, the fact remains that the focus is on the civilian population.

${ }^{13}$ James Kiras, "Irregular Warfare," In Understanding Modern Warfare, ed. James Kiras et al. (New York: Cambridge University Press, 2008), 234. 


\section{Insurgency}

The revolutionaries almost invariably find it easier to establish themselves in the 'countryside' - isolated, difficult terrain where the governing authorities are weakest, know least what is going-on, and show the least interest. Here the revolutionary political network and propagandists manage to get enough recruits to form their terrorists into small, local guerrilla bands. ${ }^{14}$

Though the "countryside" argument has been disproven by the American Revolution and American experiences in Iraq during the twenty-first century, the countryside still remains an effective place to begin. An insurgency is a threat which generally builds from within a country due to hostility toward the government or a foreign occupying power. A guerrilla war is often the vehicle by which a smaller insurgent force makes their demands known to the larger, more powerful opponent when all other negotiations have failed. In many cases, armed conflict begins by way of the guerrilla war, with the guerrilla or partisan as its warrior. Where regular armies fight in open conflict with one another on a large scale, the guerrilla often chooses to utilize hitand-run tactics whereby smaller, irregular fighting forces conduct surprise attacks on larger forces and then dissolve into their indigenous habitat. The favored techniques of insurgents include, but are not limited to: bombs and bomb making, coercion, kidnapping, assassination, terrorism, bribery, theft, and any number of other approaches that will provide expediency toward their ultimate goal. Such techniques are intended to destabilize the government or invader by constantly keeping them on the defensive against a force which they cannot directly assault due to its clandestine nature and natural cover within their own indigenous elements such as jungles, cities, and mountainous terrain.

${ }^{14}$ John J. McCuen, The Art of Counter-Revolutionary War: The Strategy of Counter Insurgency (Harrisburg: Stackpole Books, 1966), 33. 
According to Bard O’Neill, professor of international affairs at the National War College in Washington, D.C., there are three groups of people who fit the ideal criteria within an insurgency which provide favorable conditions: Parochials, Subjects and Participants. O'Neill argues that Parochials are, "Those citizens who have little or no awareness of the political system at the national level and no perception of their ability to influence it." These individuals are generally illiterate, live at the subsistence level in isolated areas and generally prefer to be left alone. Such individuals can be compared to Kurdish tribes in Anatolia, the Arabs of Saudi Arabia and the Armenians of eastern Anatolia. Subjects "have become part of the political system and are aware of its impact on their lives but are not directly active in shaping policy." Participants "are generally educated citizens who are cognizant of national political institutions and policies and wish to engage actively in the decision-making process." These individuals are generally educated, confident of their impact on policy change and vulnerable to recruitment by insurgents. This is perhaps because their involvement offers a shortcut to political recognition that would otherwise take time within a system of bureaucratic policy and regulation - a system which they already condemn. ${ }^{15}$

According to the United States Army and the Marine Corps, there are a number of different forms that an insurgency can take. ${ }^{16}$ One is of a conspiratorial nature; an example of this being the Bolshevik revolution of twentieth century Russia or the Young Turk rebellion of the Ottoman Empire in 1908. Conspiratorial insurgencies involve exactly what the name implies, groups of conspirators meeting in secret, generally

\footnotetext{
${ }^{15}$ Bard E. O'Neill, Insurgency and Terrorism: From Revolution to Apocalypse, (Washington D.C.: Potomac Books Inc., 2005), 83

${ }^{16}$ United States Department of the Army, The U.S. Army-Marine Corps Counterinsurgency Field Manual (Chicago: University of Chicago Press, 2007), 114
} 
educated, dreaming up plans to overthrow the government. Another form is of a military focused nature. Examples of this can be found all over Latin America, but perhaps the most influential would be the efforts of Fidel Castro and Che Guevara in Cuba. This form of warfare is also known as "Focoism," ${ }^{17}$ which consists of small paramilitary bands of fighters using an insurrection itself to create the conditions necessary to overthrow the government. ${ }^{18}$ Therefore, if bands of resistance fighters defy the government, the government response, which can sometimes be violent, targets any and all suspects, showing the true nature of the government and drawing attention to the guerrillas' cause. Urban insurgencies are those fought mainly in heavily populated urban centers, usually within key districts or cities which are crucial to a nations' stability. An example of this would be the efforts of Al-Qaeda, The Taliban and the IRA (Irish Republican Army). Perhaps the most recognizable form of urban insurgency would be the efforts of the IRA. They remain without question an example of what has been called a "surgical" approach to irregular warfare within the confines of an urban environment. ${ }^{19}$ Protracted Popular Warfare is the form of insurgency that Mao Tse-tung utilized in the Chinese Revolution and was later adapted by the North Vietnamese. This form of warfare is meant to create popular support for governmental reorganization by draining the enemy of resources, man power and the will to carry on the fight with a political ideology in place, which in China and Vietnam's case was communism. ${ }^{20}$

\footnotetext{
${ }^{17}$ The term was inspired by the Cuban revolution but is perhaps more recognizable as a "peoples war" and how it has since been adopted by Al-Qaeda and the Taliban.

${ }^{18}$ This has also been referred to as the "ink-blot" effect, a comparison to the nature of ink drops on paper beginning small in various locations and slowly spreading from its point of contact.

${ }^{19}$ Patrick D. Marques, "Guerrilla Warfare Tactics in Urban Environments" (M.A. Thesis, US Army Command and General Staff College, 2003) 23-24.

${ }^{20}$ United States Department of the Army, The U.S. Army-Marine Corps Counterinsurgency Field Manual (Chicago: University of Chicago Press, 2007), 9
} 


\section{Counterinsurgency}

The accumulated effect of these revolutionary wars, and there seems to be no end to them, is extremely serious and vitally concerns us all. Whatever the result, the protracted nature of each struggle does immense long-term damage, particularly to rural communities where, to add to all the other problems, the population is increasing at an alarming rate. The so-called newly emerging forces are rapidly in danger of becoming the future starving masses. ${ }^{21}$

Counterinsurgency is the process by which a government or an outside force attempts to reverse the effects of insurgency within a nation that is on the verge of internal collapse or has already imploded. According to the U.S. Army and Marine Corps, "Today, when countering an insurgency growing from state collapse or failure, counterinsurgents often face a more daunting task: helping friendly forces reestablish political order and legitimacy where these conditions no longer exist.",22

It must be said and cannot be overstated that the versatility of counterinsurgency requires a special breed of unit commander to face the challenges of such dynamic obstacles. There are a number of reasons why guerrillas/insurgents are frustrating to regular forces, but perhaps the most frustrating aspects are that they do not don conventional uniforms, they are not bound by a military code of conduct, and their support base can come from anywhere at any time. ${ }^{23}$

Guerrillas also adapt faster than regular forces because they have to and there is little doctrine behind their tactics, it is mostly theory in practice. All warfare is ever changing; however, guerrilla warfare or insurgencies are often a reaction to modernity, political change and combating the technology of the future using more elementary

\footnotetext{
${ }^{21}$ Robert Thompson, introduction to The Art of Counter-Revolutionary War: The Strategy of Counter Insurgency; by John J. McCuen (Harrisburg: Stackpole Books, 1966), 15

${ }^{22}$ US Army, Counterinsurgency Field Manual, 8

${ }^{23}$ Department of the Navy and the USMC, Small Wars Manual (Washington: The United States Government Printing Office, 1940), sect. 1-8 p. 12
} 
methods and techniques. Due to this fact, insurgents/guerrillas are typically forced to change their strategies rapidly and regularly in order to adapt and respond to their foes. So too must the counterinsurgent adapt their tactics in order to reverse engineer the effects of an insurgency.

This is exactly what Colonel John J. McCuen argued in his book The Art of Counter-Revolutionary War. McCuen, who was an expert on insurgency and served a number of staff positions in the United States, Indonesia, Vietnam, Germany and Thailand, argues that the only way to fight an insurgency is to understand its structure and principles and then reverse the effects of each based on the phase of warfare in which the insurgency resides. McCuen argues that "A major technique of revolutionary strategy is to deceive the governing authorities into making too little effort too late with tactics inappropriate to the particular stage of the war." 24 That is to say, the intent from the beginning is deception; to lure the enemy into a false sense of security so that a random strike will not only be a surprise but confusing. McCuen's book was published in 1966, making it more of a reaction to Mao's form of warfare, "the protracted war" or "people's war." The revolutionary war, which was a popular view at the time, refers to a swift form of warfare aimed at regime change, whereas an insurgency aims at resistance and denial of enemy aims.

McCuen asserts that there are four phases of strategic evolution in insurgencies. The first phase is Organization - involving the uses of propaganda and recruitment in order to supplement the ranks of the insurgency. The second phase is Terrorism, which would involve small attacks on key targets in order to draw attention to the cause. The

\footnotetext{
${ }^{24}$ John J. McCuen, The Art of Counter-Revolutionary War: The Strategy of Counter Insurgency (Harrisburg: Stackpole Books, 1966),
} 
third is Guerrilla warfare in which case the terrorist cells begin to form cohesive units and strategically carry out hit-and-run attacks. The last phase is Mobile Warfare, which is an overt war against the government. ${ }^{25}$ McCuen does stipulate that these phases often overlap each other and can occur at different phases in different parts of the same country. This is not important, however, because what truly matters for the counterinsurgent is the recognition of which phase he is combating. This is how, McCuen argues, one becomes capable of combating an insurgency. Recognition will then, by implication, lead to a reversal of the process. Counterinsurgency is not as simple as just fighting fire with fire, throwing clandestine commandos at guerrillas in the bushes, mountains and jungles.

Mao Tse-tung wrote, "What is the relationship of guerrilla warfare to the people? Without a political goal, guerrilla warfare must fail, as it must if its political objectives do not coincide with the aspirations of the people and their sympathy, cooperation, and assistance cannot be gained." 26 If the aim of the counterinsurgent is to reverse the effects of the insurgency, then he too must gain the support and confidence of the indigenous population. Mao has been widely considered one of history's greatest guerrillas/insurgents, specifically because of his expertise developed from deep philosophical reflections and a unique understanding of the Chinese people. However, his concepts and conviction were not met with immediate support. In fact, it was not until mounting Communist losses, fighting in plain sight, that Mao's approach was adopted. ${ }^{27}$

${ }^{25}$ Ibid, 40

${ }^{26}$ Mao Tse-tung, On Guerrilla Warfare, trans. Samuel B. Griffith II (Chicago: University of Illinois Press, 2000), 43.

${ }^{27}$ Beckett, Modern Insurgencies, 72. 
Mao recognized the importance and necessity of support, but he also recognized the need for regaining the upper hand through organization and support from within.

This is why it is also necessary to recognize the cultural dynamics of a conflict if one intends to combat an insurgency. McCuen focuses very little on this aspect. O'Neill states that any analysis of insurgency would be "seriously deficient" if it ignores a country's political culture. O'Neill argues, "Hence, an effort to understand and profile the political carefully is very important; in doing so, students of insurgency need to rely on the expertise of regional and country specialists, particularly historians, anthropologists, and sociologists. ${ }^{28}$ Knowing the regional dynamics is an obvious path to defeating an insurgency. Knowing one's enemy is one of the best ways to counter his efforts.

That being said, it pays to understand the indigenous population and their feelings toward the insurgency itself. One reason for this is to better understand their level of tolerance. O'Neill argues that "Where there is a low tolerance for violence, insurgent recruitment will suffer, and violent acts, particularly dramatic, terrorist ones, will probably be considered repugnant, if not counterproductive." ${ }^{, 29}$ This is an important point because it illustrates that the indigenous population can either be the greatest weapon against an insurgency or the counterinsurgents' worst fear. Take for example the negative reaction of Italians toward the Red Brigades in the kidnap and murder of Prime Minister Aldo Moro in 1978. Or, yet another example is the negative public reaction to the indiscriminate killing of foreign tourists at Luxor in Egypt in 1997. Both examples are proof that if the insurgents miscalculate the threshold of tolerance that the public has for their cause then it can break their organization. However, the same can be said of

\footnotetext{
${ }^{28} \mathrm{O}$ 'Neill, Insurgency and Terrorism, 85.

${ }^{29}$ Ibid
} 
counterinsurgents' efforts. If brutal tactics are applied in a manner that the public is not willing to accept, it can easily draw recruits to the insurgency and become counterproductive.

\section{Techniques of the Counterinsurgent}

Counterinsurgency operations are labor intensive and often depend upon a large force in order to suppress enemy forces and influence. Counterinsurgents must maintain order and security over a wide area where the insurgents only have to remain hidden and strike whenever and wherever they like. Insurgents do, however, have a number of vulnerabilities that the counterinsurgents can then utilize and exploit to their advantage in reversing the effects of an insurgency. One is their need for secrecy. The level of secrecy required in starting and maintaining an insurgency makes it very difficult for its fighters to relax and know who to trust. There is also a need to establish bases which depends on the natural cover and support of the local population, if there is one. There are inconsistencies in mobilizing guerrilla forces because of the difficulties of communication. Cohesive action as a collective unit can be difficult when there are communication challenges. There is heavy reliance on external support in order to sustain and maintain guerrilla forces with a special emphasis on financial backing. If that lifeline is ever severed then the insurgency is hard pressed to survive. There is a constant need to maintain momentum and to present a cause worth fighting for as well as a display of one's victories. This prevents desertion, internal divisions and a drop in morale. Finally, there is the greatest threat from informants within the insurgency. ${ }^{30}$

\footnotetext{
${ }^{30}$ US Army, Counterinsurgency Field Manual, 31
} 
With so many weaknesses looming within and around an insurgent organization, it would seem that combating such a threat with an overwhelming force would be easy to accomplish. However, the reality is often much different. The greatest challenge in countering an insurgency is knowing the acceptable level of force to apply. The US Army presently states that, "Extremist insurgent combatants often have to be killed. In any case, however, counterinsurgents should calculate carefully the type and amount of force to be applied and who wields it for any operation. An operation that kills five insurgents is counterproductive if collateral damage leads to the recruitment of fifty more insurgents. ${ }^{\prime 31}$ If this is the case then where is the middle ground? It is a safe assumption that a lack of force can also result in the recruitment of more insurgents because it can be interpreted as a sign of weakness. Insurgent propaganda during the recruitment phase, according to the phases laid out by McCuen, can also claim that the frailty of the enemy is an indication of success.

In many cases throughout the history of insurgencies, the indigenous forces rely heavily upon the local inhabitants for cover, food, supplies, information and communication. One way of combating the threat of insurgency's and exploiting their weaknesses, is to prevent them from establishing bases and cutting off their supply/support network. Hypothetically, counterinsurgents can try to be everywhere at once or they can remove the civilian population and establish the insurgent area as a war zone or danger zone. Anyone remaining within that zone can then be considered a combatant and dealt with accordingly. The concentrated population or deportees are then moved to a safe zone under government and local protection to establish order in an area. Such techniques are also intended to combat the insurgent threat while minimizing the

${ }^{31}$ US Army, Counterinsurgency Field Manual, 45 
collateral damage and civilian suffering, or so it is intended in planning. A reason for removing civilians from the equation is illustrated by the Department of the Navy and the USMC:

Frequently irregulars kill and rob peaceful citizens in order to obtain supplies which are then secreted in remote strongholds. Seizure and destruction of such sources of supply is an important factor in reducing their means of resistance. Such methods of operation must be studied and adapted to the psychological reaction they will produce upon the opponents. ${ }^{32}$

The statement is a compelling argument which encompasses the potential threat from an indigenous population in foreign and domestic conflicts. It also assists in illustrating the motivations for isolating civilians in areas of contention in order to weed out the threat.

32 Department of the Navy and the USMC, Small Wars Manual (Washington: The United States Government Printing Office, 1940), sect. 1-8 p.12-13 


\title{
CHAPTER III
}

OTTOMAN COUNTERINSURGENCY AND THE REBELLION AT VAN

\author{
"In war, knowing how to recognize and seize an opportunity is the most important \\ ability. ${ }^{, 33}$
}

Niccolò Machiavelli, The Art of War, 1519-1520

Study of the construction of the Ottoman Military is necessary in order to paint a more accurate picture of the Turkish soldier and their commanders. Evidence shows that there are a number of myths about the Ottoman military which must be rectified if one is to understand the mindset and the discipline of Ottoman soldiers during the First World War. This chapter also provides examples of how Ottomans dealt with rebellion in the past as well as how Western powers have dealt with them since in order to show the effectiveness of the counterinsurgency techniques which have been applied by both. This chapter demonstrates that the Armenian rebel network was both vast and sophisticated, posing a very real threat to the Ottoman empire during the First World War. And finally, this chapter demonstrates the effects of Ottoman counterinsurgency in Eastern Anatolia. Perhaps the most pertinent aspect, however, is the mindset of the Ottoman soldier and the formation of the Turkish military.

\footnotetext{
${ }^{33}$ Peter Constantine, ed. \& trans., The Essential Writings of Machiavelli, (New York: The Modern Library, 2007), 312.
} 


\section{The Ottoman Military and Popular Mythology}

According to Dr. Edward J. Erickson, military historian and retired U.S. Army Lt. Colonel, there are five myths about the Turkish military that often go unchecked. One myth is that the Germans during the First World War commanded and planned most of the Ottoman operations throughout the war. ${ }^{34}$ Statements like this have degraded the military talents of more than capable commanders in the Turkish military such as Mustafa Kemal, the man primarily responsible for the Turkish defeat of the Entente powers during the disastrous Gallipoli campaign of $1915-1916 .{ }^{35}$ Erickson says that men like Mustafa Kemal "fall into this category of audacious combat leaders without whose presence a Turkish victory is questionable. ${ }^{" 36}$ It is from this Turkish commander that the famous quote: "I do not expect you to attack, I order you to die! In the time which passes until we die, other troops and commanders can take our place!" is an example of the Turkish military mindset. ${ }^{37}$ Many contemporary scholars tend to exaggerate the influence of the contending entente powers with regard to Ottoman longevity in resisting foreign powers throughout the war. Most accounts would portray a sense of disloyalty and disunity among the entente powers as a reason for Turkish resilience. Such ideas merely ignore or underestimate the contributions of the Ottoman military, which fought a war on multiple fronts against multiple enemies, both foreign and domestic. ${ }^{38}$

\footnotetext{
${ }^{34}$ Edward J. Erickson, Ordered to Die: A History of the Ottoman Army in the First World War, (London: Greenwood Press, 2001, 214

${ }^{35}$ Erickson, Ordered to Die, 79-95

${ }^{36}$ Erickson, Ordered to Die, 85

${ }^{37}$ Erickson, Ordered to Die, 83

${ }^{38}$ Mesut Uyar, Edward J. Erickson, A Military History of the Ottomans: From Osman to Ataturk, (Santa Barbara: ABC CLIO, 2009), 282
} 
The second myth is that the Ottoman government and the Turkish military kept poor records. ${ }^{39}$ Nothing could be further from the truth. Erickson argues that "the Ottomans literally invented bureaucracy and red tape, and they kept most of their records no matter how trivial," and that "The Turkish General Staff Archives alone contain 1.5 million documents on the First World War." ${ }^{, 40}$ This is at least some indication of the obsessive record keeping of the Ottomans. A problem which is often overlooked is that many scholars rely mainly on Western sources rather than Ottoman records because they are primarily in Turkish.

The third is that Ottoman units were prone to desertion during combat and that they had a tendency to disintegrate under the pressure of war. The truth is, according to Erickson, that the units which had historically suffered mass disintegration were in fact non-Turkish formations of only regimental strength and below. Erickson argues that "Desertions occurred primarily during unit movements across the empire, during lulls in action, and from hospitals in the rear areas." ${ }^{, 41}$ These desertions are emblematic of the Kurdish and various Arab tribesmen who were often used by the empire to supplement its lacking cavalry strength, men who generally only maintained an allegiance to money or tribe. Military history of World War I has shown time and again that the Turkish military strength consisted mainly of a strong defense and unwavering resolve. The book Caucasian Battlefields by Allen and Muratoff has become one of the best known works on the Eastern Anatolian campaigns from 1828 to 1921. The book regularly references

\footnotetext{
${ }^{39}$ Erickson, Ordered to Die, 214

${ }^{40}$ Ibid

${ }^{41}$ Ibid
} 
the courage and "traditional stubbornness in defense," which characterizes the Turkish military. ${ }^{42}$

The myth of desertion is linked to what has also been claimed as an unusually high rate of casualty in the Ottoman Empire. The fact is, however, that many sources are based on over estimated Russian sources and also do not account for loss due to the elements such as disease, starvation and frostbite. According to Erickson, "The actual combat related loss rate (10.6 percent) was similar to that of other combatants. Disease was the great killer of men, particularly in Mesopotamia and in Caucasia." ${ }^{, 43}$ Eastern Anatolia often witnessed the overly ambitious machinations of Enver Paşa, Minister of War in the Ottoman Empire. The grand plans of Enver Paşa often required the Ottoman military to perform incredible feats with very little support. One example is that of the Sarıkamış campaign of $1914^{44}$, in which the military traversed hundreds of miles of brutal mountain terrain with little food, equipment and clothing, resulting in the loss of around 75,000 men and most of their artillery, a substantial part of the Turkish III army, according to Allen and Muratoff, among others. ${ }^{45}$ According to Edward Erickson, however, the number of casualties is closer to $50,000 .^{46}$ The Turkish III army was comprised of the empire's seasoned battle veterans who did not require additional training. They were the men who trained the others, a valuable resource within a military stretched so thin. This debacle right at the outset of the war undoubtedly crippled the Ottoman defense and preparation strategy even more than it had been already.

${ }^{42}$ W.E.D Allen, Paul Muratoff, Caucasian Battlefields: A History of the Wars on the TurcoCaucasian Border 1828-192, (Cambridge: Cambridge University Press, 1953), 39

${ }^{43}$ Erickson, Ordered to Die, 215

44 This is an important aspect in reviewing Ottoman military history because the defeat at Sarıkamıs came just one year before the Armenian rebellion at Van, at a time when the Ottoman military had already been stretched thin and resources, both materially and in knowledge were in short supply.

${ }^{45}$ Allen and Muratoff, Caucasian Battlefields, 284

${ }^{46}$ Erickson, Ordered to Die, 60 
The last myth refers to Enver Paşa and the plans of the CUP (Committee of Union and Progress). ${ }^{47}$ The assumption is often that Enver Paşa and the CUP intended to regain the land that had been lost during the previous wars in the Balkans and the land in the East during the Russo-Turkish war of 1877-78. This is based on the notion of PanTuranism, or the unification of Muslims throughout the Empire and elsewhere under a common ethnic connection with the Ottoman Turks at the heart of the movement. According to Erickson and others, the reality is that a massive Ottoman offensive in the East was merely the result of timing and advantage in the wake of the Russian revolution rather than a part of carefully formulated military strategy. Erickson argues that "This is illustrated by the fact that the recovery of irredentist territory in Caucasia or in the former Turkey-in-Europe never appeared in the prewar campaign planning process."48

\section{Formation of the Ottoman Military and the Situation in the East}

"Probably the greatest injustice done to this magnificent fighting army was the gross distribution of its reputation, its ethos, and its character by erroneous historical perceptions." 49

Prior to the 1860 's, the Ottoman Military had been constructed over the years in such a way that it was more about loyalty to the Sultan than tactics and restructuring. Up to this point in history, the Ottomans had been defeated by their European enemies again and again with very little time in between to incorporate the much needed reforms that were well overdue. At the time, there had existed a system of combating new problems

\footnotetext{
${ }^{47}$ "The Young Turk movement attracted an unusual mix of Turks, including intelligentsia, liberal thinkers, as well as numerous military and naval officers. The most prominent of these groups was the Committee of Union and Progress (CUP). Naturally this movement was perceived as a threat to the sultanate of Abdulhamit II, who sought to suppress it both inside and outside of his empire. The army officers who secretly joined these groups maintained active cells in Damascus and Salonika."( See Erickson, Ordered to Die, 1)

${ }^{48}$ Erickson, Ordered to Die, 214

${ }^{49}$ Erickson, Ordered to Die, xix
} 
with old tactics. ${ }^{50}$ It is also worth noting that the Ottomans could barely afford to pay their soldiers after years of constant warfare and loss, let alone invest in artillery and naval gunships. Fortunately, out of the Balkan wars of the nineteenth century, there emerged a new corps of well trained officers within the Ottoman military structure which "revitalized the army." "5r Prior to the reforms of the 1860 's, the glaring weakness of the Ottoman military corps had been the incompetency of its officer corps with regard to training and tactics. ${ }^{52}$ Therefore, the Ottomans recognized an opportunity to invest in their leadership instead. The defeat of the Ottomans in the East by General Peskevich and the Russians, as well as the Egyptian Army of Mehmet Ali during the thirties, was at least some indication that the Ottomans were the weakest on their Asiatic Frontiers. ${ }^{53}$

Prussian prestige was beginning to replace that of the British. German advisors began to replace British, Polish and Hungarian émigré officers which had carried over after the Crimean War of $1853-1856 .^{54}$ It was between the Crimean War and the 1877-78 Russo-Turkish War that the Ottoman reforms began to take effect in the military. New officer school curriculums were developed to focus more on tactics than technical training and theory. Unfortunately, even with the advancements in curriculum, the Ottoman government ultimately could not afford the field training that was desperately needed to train new recruits and new commanders. ${ }^{55}$ Regardless, Ottoman success can be

${ }^{50}$ Uyar and Erickson, A Military History of the Ottomans, 203

${ }^{51}$ Uyar and Erickson, A Military History of the Ottomans, 175

${ }_{52}^{52}$ Allen an d Muratoff, Caucasian Battlefields, 113

${ }^{53}$ Allen and Muratoff, 109

${ }^{54}$ Allen and Muratoff, 111

${ }^{55}$ Prior to the Ottoman losses in the Balkans, and according to general military standards, even as they are today, it was preferable to utilize live fire exercises in battle training in order to provide the new recruits with a closer understanding of war. However, the Ottoman government could not afford to spare the money, time and supplies necessary to fulfill the live fire training exercises. 
directly linked to this new school of thought since the 1860 's ultimately represented a "renaissance of Ottoman military capacity." 56

Unfortunately for the Ottomans, the Officer corps was not enough to salvage their lacking cavalry and manpower when compared to the Russians in the 1877-78 war. As Erickson argues, the cavalry of the Ottomans was their main military weakness in every action during the Russo-Turkish war. Poor cavalry meant an inability to match one's enemy on the battlefield in an assault, an inability to protect your troops during a retreat and also to pursue Russian forces in retreat after an Ottoman victory. ${ }^{57}$ The Turks, whose defensive proficiency cannot be stressed enough, often fought from a fortified position in Eastern Anatolia. Therefore, having defeated a Russian force attacking their position, it would have been crucial to pursue them as they fled. Without cavalry this was not feasible and would have been dangerous for Ottoman forces if they pursued on foot, not only in weakening defenses but also risking vulnerability during a counter attack. This helps to explain, in part, one major reason why the Ottomans were unable to defeat the Russians.

The new Ottoman officer corps (Mekteblis, roughly "Academy Graduates") remained an untapped resource during the Russo-Turkish war. Due to infighting and distrust among the general staff of the Ottoman military hierarchy -- mainly fueled by Sultan Abdulhamid II himself to maintain control of the throne - "each group or division commander saw his unit as his personal fiefdom and paid attention only to his immediate area of operations." ${ }^{, 58}$ The condition of the Ottoman general staff and military leadership without a doubt resulted in the rise of the "Young Turks," who would later take control of

\footnotetext{
${ }^{56}$ Uyar and Erickson, A Military History of the Ottomans, 175

${ }^{57}$ Uyar and Erickson, A Military History of the Ottomans, 188

${ }^{58}$ Uyar and Erickson, A Military History of the Ottomans, 194
} 
the government and overthrow Sultan Abdulhamid II. The new guard of the officer corps rivaled that of the old in their training. Therefore, the lack of cooperation among military units in the interest of self preservation undoubtedly weakened the effectiveness of the Ottoman military.

It was for this reason, coupled with reasons of poor equipment, fiscal strain and minimal time to prepare for war that the Ottomans were left wanting on the Anatolian front. In the Southern Caucasus and Eastern Anatolian regions along the Russian border, repelling Russian attacks with so little was toilsome and back-breaking work. Ottoman forces were stretched thin across a vast border in hellish terrain with little supply. Also, it must be mentioned that due to the situation along the Russian border, which was a reoccurring theme, the Ottomans also had to combat the problem of Kurdish raiders and Armenian partisans.

Gendarmes, or the policemen of the Ottoman East, had generally been entrusted with the protection and security of the people of the Empire in Anatolia. It was in the interest of the Ottomans to protect their subjects for the purposes of tax collection. ${ }^{59}$ During wartime, however, gendarmes would be called away to supplement the lacking forces in the Ottoman military. ${ }^{60}$ In 1876 , the population of the Ottoman Empire was around 22 million people. Of these subjects, only about 16 million (12 million in Asia and 4 million in Europe) were eligible for military service, due to the fact that the

${ }^{59}$ Justin McCarthy et al. The Armenian Rebellion at Van, (Salt Lake City: The University of Utah Press, 2006), 37

${ }^{60}$ Justin McCarthy, Death and Exile: The Ethnic Cleansing of Ottoman Muslims 182 I-1922, (Boston: Darwin Publishers, 1995), 42 
Ottomans only allowed Muslims to serve in the regular army. This meant that the Turks were perpetually outnumbered by the Russians $2: 1$ at nearly every military engagement. ${ }^{61}$

The lack of manpower dedicated to protection made Eastern Anatolia unique.

Religion had always been a factor in the Ottoman Empire and ultimately determined who you were and where you lived rather than any kind of ethnic stratification. In the East, the majority of the population was peasantry, attempting to make a living and provide for their families in harsh terrain. Affiliations were with one's religion and the same conditions remained for the Kurds that also inhabited Eastern Anatolia. ${ }^{62}$ Most importantly, though, was the significance that religious denomination had regarding loyalty and alliance. Due to their Christian affiliation with the Russian Orthodoxy and a hatred of their Muslim overlords, Justin McCarthy argues that "During the 1700's and 1800 's, Armenian secular and religious officials supported the Russian invasion of the Muslim Khanates in the Caucasus and the overthrow of their Muslim rulers," and that at the same time, Armenians acted as spies for the Russians. ${ }^{63}$ In terms of internal security in the East, this is what the Ottomans were faced with among the many other problems plaguing the empire by the end of the nineteenth century.

${ }^{61}$ Allen and Muratoff, Caucasian Battlefields, 111

${ }^{62}$ Justin McCarthy, Death and Exile: The Ethnic Cleansing of Ottoman Muslims 1821-1922, (Boston: Darwin Publishers, 1995), 26

${ }^{63}$ McCarthy, Death and Exile, 27 


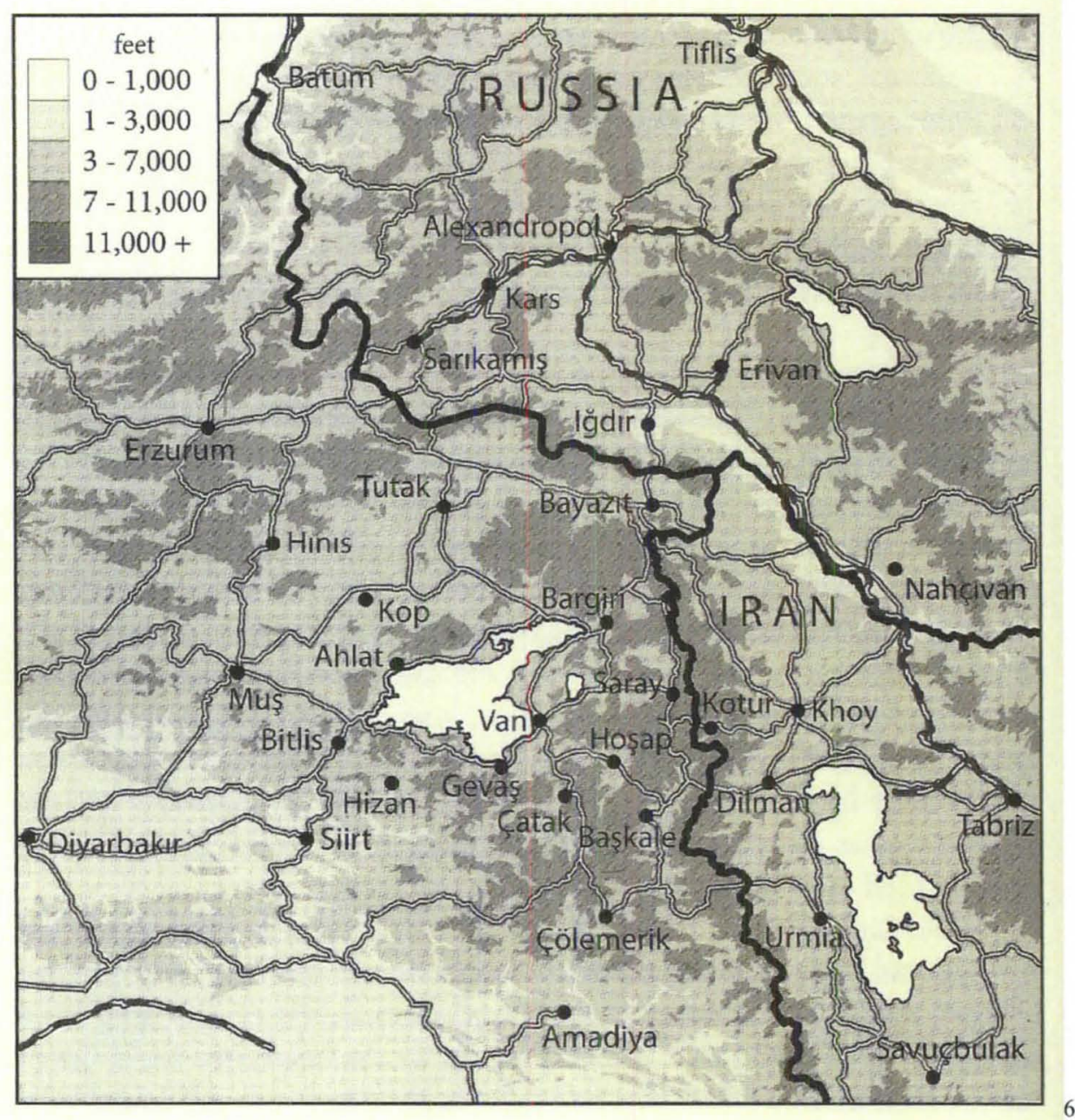

64

\section{Ottoman Counterinsurgency Heritage}

"Similar to the French and British colonial experiences with low-intensity conflicts or small wars, the Ottoman officers spent an important percentage of their careers fighting against various types of insurgents, social bandits, and tribal warriors. Their continuous occupation with counterinsurgency operations left its stamp on the identity and performance of these officers. It is nearly impossible to understand the political and military developments of the time without paying attention to this counterinsurgency heritage. $" 65$

Internal security threats were not unknown in the Ottoman Empire prior to the

First World War. Quite the opposite is true; they were experts in dealing with insurgency

\footnotetext{
${ }^{64}$ McCarthy, Justin. Roads and Railroads [map]. Scale not given. In: Justin McCarthy. The Armenian Rebellion at Van. Salt Lake City: The University of Utah Press, 2006, p. 168

${ }^{65}$ Uyar and Erickson, A Military History of the Ottomans, 212
} 
both politically and militarily. As previously mentioned, the main concern of the Ottoman government during the early and mid-nineteenth century was the constant threat of Kurdish tribesmen who capitalized on turmoil through raids and highway robbery. The Ottoman way had always been able to deal with them either by force with a show of military might or with the occasional bribe. The average person was indifferent in the East regarding rebellion and the same was true of the Kurds. There was no inherent loyalty to one political ideology or another, the focus was mainly on religious affiliations. Like most in the Eastern Anatolian region, they just wanted to be left alone ${ }^{66}$ According to McCarthy, "Those who were a disruptive force were tribal groups, and their loyalties were tribal... If tribes cooperated, it was out of mutual benefit, not ethnic loyalty, for which there is no evidence., ${ }^{, 67}$

It was no secret that upheaval in the East during wartime meant that the Ottomans would have to respond and had the potential to weaken their abilities in battle as a whole. That is why Kurdish tribes often capitalized on the chaos during wartime. Raiding and theft were commonplace in the East, and the peasantry were often left to fend for themselves when Ottoman forces were stretched too thin as they often were. Poor roads and rough terrain also slowed the Ottoman response time to crises in the East and by the time Ottoman forces would arrive it was often too late. In such situations, it is difficult to imagine the emotional backlash of witnessing such atrocities for soldiers. That is undoubtedly why the Turkish response was often harsh and exacting upon those believed to be responsible.

\footnotetext{
${ }^{66}$ McCarthy, Death and Exile, 40

${ }^{67}$ McCarthy, Death and Exile, 41
} 
The Serbian rebellion of 1875 and the Bulgarian Revolution of 1876 in the West is an example of how the Ottomans responded to rebellion in the Balkans, and also an example of how such actions can influence others. The Balkan region was a major source of conflict and turmoil as well as a potential bargaining chip in the European balance of power. The Serbian rebellion in Bosnia began with refusal to pay Ottoman taxes, leading to attacks on officials and eventually Muslim villagers, which of course demanded a response from the Ottoman military. The Turks responded with a force to quell the rebellion led by Ahmet Muhtar Pasha. This gradually drew attention from the European powers and ultimately increased an existing public outcry for the allowance of Bosnian autonomy.

The Bulgarians, capitalizing on the situation in the West, saw an opportunity to try for autonomy as well and began a revolution against the Empire in May of 1876. As was seen later in the East, both rebellions had outside assistance from Montenegro and Serbia who shipped arms and supplies, eventually entering the conflict directly. The Serbian and Bulgarian rebels attacked civilians which were met in kind with Turkish military force. The Ottomans eventually quelled the rebellions in Bosnia and Bulgaria and defeated Serbia and Montenegro. ${ }^{68}$ This victory inevitably led to the Russo-Turkish war of $1877-78$ and the consummate creation of a Bulgarian state. What became known as the "Bulgarian Horrors" of 1876 had unquestionably begun with the slaughter of innocent Muslims, though it was largely unreported. ${ }^{69}$

The organizers of the Bulgarian revolution saw an opportunity to take advantage of the Turkish vulnerability during the Bosnian revolt. The first villages to face the

${ }^{68}$ Justin McCarthy, Population History of the Middle East and the Balkans, (Istanbul: The Isis Press, 2002), 169-170

${ }^{69}$ McCarthy, Death and Exile, 59 
revolutionary tide were Koprivshtitsa, Panagiurishte, and Klisura. ${ }^{70}$ Thanks in part to the rhetoric of the rebel leader of the Bulgarian revolution, named Georgi Benkovski, about 1,000 Muslim villagers were killed. Unfortunately, while the regular Turkish army had been known for its restraint and obedience, the irregular forces were not. The regular Turkish army was tied up with the Bosnian revolt and the Ottoman government feared that the rebellion would quickly spread if not crushed immediately. Therefore, in order to supplement the lacking troops, the Ottomans armed the indigenous Muslim civilians (Başi Bozuks) and Circassian irregulars which had been used many times before. These irregulars were not known for their restraint, and as custom had dictated for centuries, they obeyed the orders of their immediate tribal superiors rather than orders from the Ottoman military. $^{71}$

The Circassians particularly were accustorned to a nomadic style of warfare, roaming in search of hospitable terrain and opposing those who opposed them, which entailed raids and violent reprisal. Based on their experiences in the Caucasus fighting the Russians, they had come to hate Christians for previous acts of violence against their people and forcing them from their homeland. ${ }^{72}$ Perhaps because of this tainted past between the two groups, McCarthy suggests that the Bulgarian insurgents may have been aware of the response they would receive from the Circassian irregulars, and that they could potentially utilize such violent methods in their favor. McCarthy says that "By always burning at least one Circassian village, they insured that the Circassians would commit atrocities in reprisal. In areas of Bulgaria where the revolution took hold, the insurgents committed acts of violence, particularly against Muslim women, with the

\footnotetext{
${ }^{70} \mathrm{Ibid}$

${ }^{71}$ McCarthy, Death and Exile, 60

${ }^{72}$ Ibid
} 
obvious intent of sparking a retaliation."73 This is important to remember because the Circassians were a source of Ottoman irregular forces.

The idea of utilizing the suffering of others for the greater good in terms of social revolution and autonomy from the Ottoman Empire may seem like a cold and unfeasible solution for the Bulgarians. However, the awareness of Western media and Western support for their actions against their Muslim oppressors was well known by the Bulgarians, recognizing that the eyes of the Christian nations of Europe were upon them. One such example is when the English press ran stories about the atrocities of the Turks and the kidnapping of Christian girls who were later sold into slavery in Turkish harems. ${ }^{74}$ There was no truth to the story whatsoever, proven later by European consuls, but stories like this had a profound effect on the Western psyche. The Armenians would later attribute their revolutionary aims to be that of the Bulgarians by which they would draw attention to their struggle, committing atrocities against Muslims with the intent of generating Armenian slaughter as a result. The idea being, just as had happened previously in the Balkans, Europe would intervene on their behalf and create an Armenian nation just as the Bulgarians had received. ${ }^{75}$

Muslim suffering did not end with an Ottoman victory over the Bulgarians. The result was a Russian invasion in the West and the subsequent murder of countless Muslim villagers at the hands of Russian troops and Bulgarian irregulars who sided with Russia. As previously stated, the Ottomans were not the only ones to use unconventional tactics to achieve military aims. The Russian method consisted of sending their most feared and most skilled units in unconventional warfare known as the Cossacks. In order to create a

\footnotetext{
${ }^{73}$ Ibid

${ }^{74}$ McCarthy, Death and Exile, 62-64

${ }^{75}$ McCarthy, The Armenian Rebellion at Van, 60
} 
Bulgarian state and to insure Russian supremacy in the region, it had to be Muslim free; a task which was entrusted to the Cossack units sent to the region. As McCarthy says, "What was needed was a combination of murder and fear that would either kill the Muslims outright or cause them to flee from impending murder. To accomplish this, the most suitable force in the Russian army was the Cossacks."

Russian and Bulgarian terror campaigns were meant to frighten, displace and eliminate Muslim opposition as well as the Muslim population as a whole. By disarming Bulgarian Muslims and turning their weapons over to Bulgarian Christians siding with Russia, the object was to destroy their homes so they had nothing to return to when hostilities ended.

"For Example, in the village of Hidibey, Cossacks peacefully took the arms of the Turkish villagers and gave them to the Bulgarians, who then killed all but 15 of the 70 Turkish males of the village, while the Cossacks made sure that none escaped. The 15 who did escape had fled as soon as the Russians were sighted. In the Buklumluk, the Cossacks again took the Turk's weapons and gave them to the Bulgarians. The Cossacks 'cordoned off the town' to prevent escape. The Bulgarians put all the men in a straw barn and all the women and children in houses. The barn and the houses were piled with straw and set afire. Those who ran from the buildings were shot by the Bulgarians." 77

It is unlikely that there was any real strategic value to such attacks on civilians within the mindset of Russian and Bulgarian soldiers. The violence of the 1877-78 war was undoubtedly carried over in the collective mindset for the atrocities on both sides during the 1876 revolt. Instructions for soldiers on how to incite rage and hatred would have been highly unlikely. Rather, the differences were primarily religious and the men who faced the horrors of war would not have forgotten what had happened to their families and countrymen on both sides of the conflict. Unfortunately, it was primarily the civilians who suffered during the war, as they generally do in all wars; the result of which is a

\footnotetext{
${ }^{76}$ McCarthy, Death and Exile, 68

${ }^{77}$ McCarthy, Death and Exile, 69
} 
deep, enduring hatred for one's enemy. This is not only remembered by the soldiers of the conflict itself, but also a lesson taught to the children who survive to be acted upon in the future.

\section{Preparations for War and the Threat of an Armenian Fifth Column}

"In guerrilla units some individuals have developed strong ideological motives for taking up arms. These ideologies take root in two broad areas - politics and religion. The individual tends to subordinate his own personality to these ideologies and works constantly and solely for the 'cause.' In some resistance fighters, this motive is extremely strong." 78

The lessons that the Turks had learned from the Balkans and the Russo-Turkish war of 1877-78 was that a European style time-table was "unsuitable" for future combat due to poor communication lines. Also, the immense setbacks suffered in previous wars had an even greater impact with regard to losses of equipment, trained leaders and experienced battle formations. The loss of the entire Second Army (12 regular infantry divisions) in 1914 and most of the First Army meant that focus would have to be on the reconstitution of forces rather than training. This made the German mission to assist the Turks in restructuring all the more difficult. Where the Turks and Germans could have planned for successful offensive operations, had the military been in better standing, they now had to focus primarily on reconstitution and hope for the opportunity to seek an effective offensive strategy. ${ }^{79}$

Keeping this in mind, it also meant that throughout the planning prior to World War I, the Young Turks were more concerned with restructuring and diplomacy rather than internal security. Erickson argues that "because of the Young Turks' propensity to

\footnotetext{
${ }^{78}$ Department of the Army, U.S. Army Guerrilla Warfare Handbook, (New York: Skyhorse Publishing Inc., 2009), 6

${ }^{79}$ Erickson, Ordered to Die, 23
} 
conduct diplomacy (and their affairs in general) in isolation, that at any given time between August and November of 1914, no single individual within the Turkish government (including either Sait Halim, the Grand Vizier, or Enver Paşa, the Minister of War) had a global awareness of the entire diplomatic situation affecting the empire."80 Perhaps in spite of this, the Turks did not fully realize the potential threat of the Armenians in the East. Leading up to the war, the CUP had tried to appease the leading Armenian party in the East in order to prevent any kind of popular uprising that might threaten the empire during wartime. ${ }^{81}$ At the beginning of World War I, the concentration of Russian forces was in the West fighting the Austrians and Germans. Therefore, in the East, in the Caucasus, they only needed to hold out against the Turks until they could be spared reinforcements. In the meantime, it was as the Ottomans had done before, the Russians now had to defend the lines in the Caucasus.

Enver Paşa realized this and must have seen it as an opportunity to break the Russians in the East before the war gained momentum. The old European concept of perpetual offensive attack was undoubtedly a factor in his military stratagem. Among his grandiose inventions was a debacle known as the "Grand Turanian Offensive." In December of 1914, Enver envisioned an opportunity to break the Russians in the East, gaining a foothold for the rest of the war in Anatolia. His plan was to attack a railway in Sarıkamış which was reinforced with a small Russian force by attacking through the mountains and surprising the Russians. The Russians were indeed surprised because, given the weather conditions and the difficulty of the assault, the mission was essentially suicide. Allen and Muratoff argue that the plan had no real chance of success. The plan

${ }^{80}$ Erickson, Ordered to Dies, 30-31

${ }^{81}$ McCarthy, The Armenian Rebellion at Van, 133 
needed more men and more time to prepare but Enver did not want to allow such an opportunity to slip away. ${ }^{82}$ Though, even with an abundance of time and troops, an offensive during the winter months was destined to fail.

The fighting for Sarıamıs throughout January of 1915 resulted in the loss of about 50,000 soldiers from the Turkish III Army and most of their artillery. The Russian losses were about 16,000 killed and wounded with roughly 12,000 sick - mostly from frostbite. ${ }^{83}$ Enver tried to cover up the losses at Sarıkamış but the damage was already done. The Turkish forces now had to be recovered and the army restructured to fulfill regimental requirements. The Turks fortunately had the reserves of men available but were severely deficient in weapons and ammunition. The Turks soon caught wind of a potential allied invasion of the Dardanelles and their focus began to shift from the East to their defenses in the West. ${ }^{84}$

The offensive of Enver Paşa and subsequent failure at Sarkamış ended any chance of an Ottoman offensive against the Russians for at least two years. Though, the $3^{\text {rd }}$ Army had begun with their overall effective troop strength at about 118,174 in December of 1914 , only 8,900 remained after Sarkamış. ${ }^{85}$ The Turks had become significantly weakened in the defense of Eastern Anatolia and afforded revolutionary Armenian elements to flourish virtually unabated. Anatolia was a core region in the defense of the empire and with Ottoman presence lacking in the east, the Russians were able to capitalize on faltering Ottoman intelligence and logistics by supporting an already hostile Armenian environment in Van.

\footnotetext{
${ }^{82}$ Allen and Muratoff, Caucasian Battlefields, 284

${ }^{83}$ Allen and Muratoff, Caucasian Battlefields, 285

${ }^{84}$ Allen and Muratoff, Caucasian Battlefields, 286

${ }^{85}$ Uyar and Erickson, A Military History of the Ottomans, 248
} 


\section{Border Security and Armenian Operations}

Armenian discontent and revolutionary organization can be traced back as early as the 1870 's. Erickson argues that "While many of the Armenians were loyal and law abiding citizens of the empire there had existed for many years subversive Armenian societies dedicated to the establishment of an autonomous Armenia." $" 86$ Two parties in particular sowed the seeds of rebellion from within which were known as The Union of Salvation (founded in 1872) and the Black Cross Society (founded in 1878). The inception of these parties is not as important as their influence on those to follow. They were proof that revolutionary organizations were able to function effectively and efficiently with minimal Ottoman opposition. They were also proof that with proper leadership, rebellion could flourish while preaching violent revolution. Though these two groups did not perform revolutionary acts, they were undoubtedly the inspiration for those that did. Among the groups to follow were the Armenakan Party (founded 1885), the Hunchakian Revolutionary Party (founded in 1887) and the Armenian Revolutionary Federation (ARF or Dashnaks founded in 1890). ${ }^{87}$

Within the Ottoman documents titled Arşiv Belgeleriyle şiirlerini Faaliyetleri 1914-1918 Cilt I (Armenian Activities in the Archive Documents 1914-1918 Volume I), there are nearly fifty pages of "interviews" conducted from May 4 to May 12,1915 . The “interviews", conducted by the Second Police Chief Ahmet Lütfi, were gathered from various members of the Hunchak and Dashnak Armenian parties in an attempt to understand the leadership hierarchy of the organizations in various districts and villages

\footnotetext{
${ }^{86}$ Erickson, Ordered to Die, 96

${ }^{87}$ McCarthy, The Armenian Rebellion at Van, 41-43
} 
throughout Anatolia. The "interviews" place emphasis on party affiliation and board members identities in order to uncover the extent of the Armenian revolutionary network. Chief Lütfi asked questions such as: "Who were the members and the administrators of your committee? Please tell us their names... Where did you hide your association's weapons, arsenal?... Where are the documents and the registry books of the association?"88 These "interviews," though they would more likely be categorized as interrogations, are at least some indication of the threat posed by the two major Armenian revolutionary groups. They also portray the Ottoman Empires' concern with the identities of their leaders and the location of their weapons caches. From a counterinsurgency perspective, the Ottomans most certainly placed the gathering of intelligence on insurgent activity at the top of their list.

The Dashnaks, who were to become the most influential revolutionary group of the insurgency, were socialists in their ideology, much like the Hunchaks. They drew inspiration for armed insurrection from Marxism and preached the necessity of arming a civilian population in order to achieve "political and economic liberty in Turkish Armenia" through such means. ${ }^{89}$ It was believed by the Armenian revolutionaries that through sabotage missions, the execution of government officials and Armenian "traitors" who were unsympathetic to their cause, they would gain recognition and ultimately autonomy. ${ }^{90}$ Human suffering was unavoidable and it was necessary to mobilize the population in favor of a popular revolt if they were to succeed, not to mention generating European support in the process.

\footnotetext{
${ }^{88}$ Turkey, General Staff Command, Arşiv Belgeleriyle șiirlerini Faaliyetleri 1914-1918 Cilt I, (Ankara: Genel Kurmay Basım Evi, 2005), 261-262

${ }^{89}$ McCarthy, The Armenian Rebellion at Van, 43

${ }^{90}$ Ibid 
In discussing the revolution with Dr. Hamlin, founder of Robert College, ${ }^{91}$ one of the revolutionaries told Hamlin that Hunchak bands would "watch their opportunity to kill Turks and Kurds, set fire to their villages, and then make their escape into the mountains. The enraged Moslems will then rise, and fall upon the defenseless Armenians and slaughter them with such barbarity that Russia will intervene in the name of humanity and Christian civilization." When Hamlin vehemently opposed the plan and its "atrocious" nature, the revolutionary responded: "It appears so to you, no doubt; but we Armenians have determined to be free. Europe listened to the Bulgarian Horrors and made the Bulgarians free. She will listen to our cry when it goes up in the shrieks and blood of millions of women and children...we are desperate, we shall do it." ${ }^{, 92}$

Most likely, the reason for such extreme measures was an attempt to draw others to their cause within the community through a demonstration of power. It is also a clear example of terrorist strategy in practice. Regarding security in a guerrilla insurgency operation:

"If the resistance movement is strong or gives the impression of being powerful, many individuals join out of a feeling of personal safety. Usually, this situation occurs only after the resistance movement is well organized and the enemy has been weakened by other actions. Others join in order to escape recruitment into the service of the enemy." 93

Security from vengeful Ottoman troops would be powerful motivation if one were anticipating reprisal for what others had done. Also, after the Balkan wars, the new leadership in the Ottoman military enforced conscription regulations of non-Muslims,

${ }^{91}$ Robert College was perhaps the greatest example of Western Missionary influence in the Ottoman Empire. It was founded in the 1860's in Constantinople, and was intended to offer a higher level of education to the indigenous population as opposed to the basic teachings and introduction of Western ideas in the existing elementary schools. Enrollment heavily increased with a wider range of academia such as science, theology, morality, mathematics and languages. However, the employment of the printing press was perhaps the most influential in disseminating Western concepts abroad. (See Robert L. Daniel, American Philanthropy in the Near East [Athens: Ohio University Press, 1970], 71-73)

${ }^{92}$ McCarthy, Death and Exile, 118

${ }^{93}$ Department of the Army, Guerrilla Warfare Handbook, 7 
recognizing the danger of a Russian invasion. Among these newly drafted soldiers were Armenians who had already been exposed to revolutionary propaganda. Most of these recruits can be linked to the high desertion rate in the Ottoman military, as Uyar and Erickson argue that "very few of them were willing to fight and risk their lives for the sake of the empire. As could be expected, the desertion rates of non-Muslim recruits set record highs. They fled or surrendered at the first opportunity, which verified the suspicions that Muslim soldiers held towards thern." $" 94$ Their flight from the Ottoman ranks undoubtedly supplied the Armenian weapons caches that would later be discovered by the Turks.

European pressure had perhaps been the most damaging to the Ottoman counterinsurgency efforts. Proven effective previously in the Balkans, fighting insurgents meant also punishing those responsible for their support. ${ }^{95}$ This could not be achieved while Europeans continued to slant the news in favor of their downtrodden Christian Armenian brethren in the East. Ironically enough, McCarthy points out that "The same Europeans who complained bitterly whenever the Ottomans imprisoned Armenian rebels voiced constant complaints that the Ottomans were not forceful enough in dealing with the Kurdish tribes. ${ }^{96}$ Perhaps their sympathies were only limited to members of a congregation.

Indeed it was no secret that there was Christian support for the Armenian rebel cause. According to the Ottoman government documents, there was in fact an order issued on May 23, 1915 detailing the procedures in handling "Christians who are allies of

\footnotetext{
${ }_{95}^{94}$ Uyar and Erickson, A Military History of the Ottomans, 234

${ }^{95}$ McCarthy, The Armenian Rebellion an Van, 48

${ }^{96}$ McCarthy, Death and Exile, 47
} 
the enemy and Muslims who collaborate with them."97 The order was essentially a call for the investigation of Christians suspected of supporting the Armenian revolutionaries and for their homes to be searched. Those found to be guilty of supporting the Armenian revolutionaries were to be punished by court martial.

For over a decade prior to World War I the Ottomans had also been forced to practice a cautious approach to opposition in the East regarding Kurdish tribes, who had formerly been the empire's greatest internal irritation in Eastern Anatolia. Although the Kurdish tribes proved an annoyance in the past, their skills in battle and the use of their cavalry in irregular formations was an important aspect of Ottoman defense in the region. What was ultimately required at the time in the East was a larger police force or Gendarmerie, which the Ottomans could not spare. What was used in their place became a mistake that the Armenians would not soon forget. Sultan Abdulhamit II created the Hamidiye, an irregular Kurdish force intended to solve the military's security problem in the East in 1890, a group whose application played a significant role in stopping the Armenian rebellion of $1896 .^{98}$

Whereas, the Armenian revolutionaries had sometimes cooperated in the rebellions of the 1890 's, their failures led to splintering among the parties. Specifically, a division had developed between the two strongest parties - the Dashnaks and the Hunchaks - in which case the responsibility of leadership was ultimately thrust upon the Dashnaks. ${ }^{99}$ Erickson argues that "By 1914, nationalist/revolutionary Armenian societies were operating openly in Europe and in Russia and were receiving support from many

${ }^{97}$ Turkish Republic Prime Ministry, Armenians in Ottoman Documents: 1915-1920, (Ankara: Directorate of Ottoman Archives, 1995), 37

${ }^{98}$ McCarthy, The Armenian Rebellion at Van, 58-59

${ }^{99}$ McCarthy, The Armenian Rebellion at Van, 85 
sources that sought the dismemberment of the Ottoman Empire."100 Ottoman power had virtually ended in Europe with their defeat in the Balkan wars and the Armenian revolutionary organizations would have been able to conduct subversive planning without interruption.

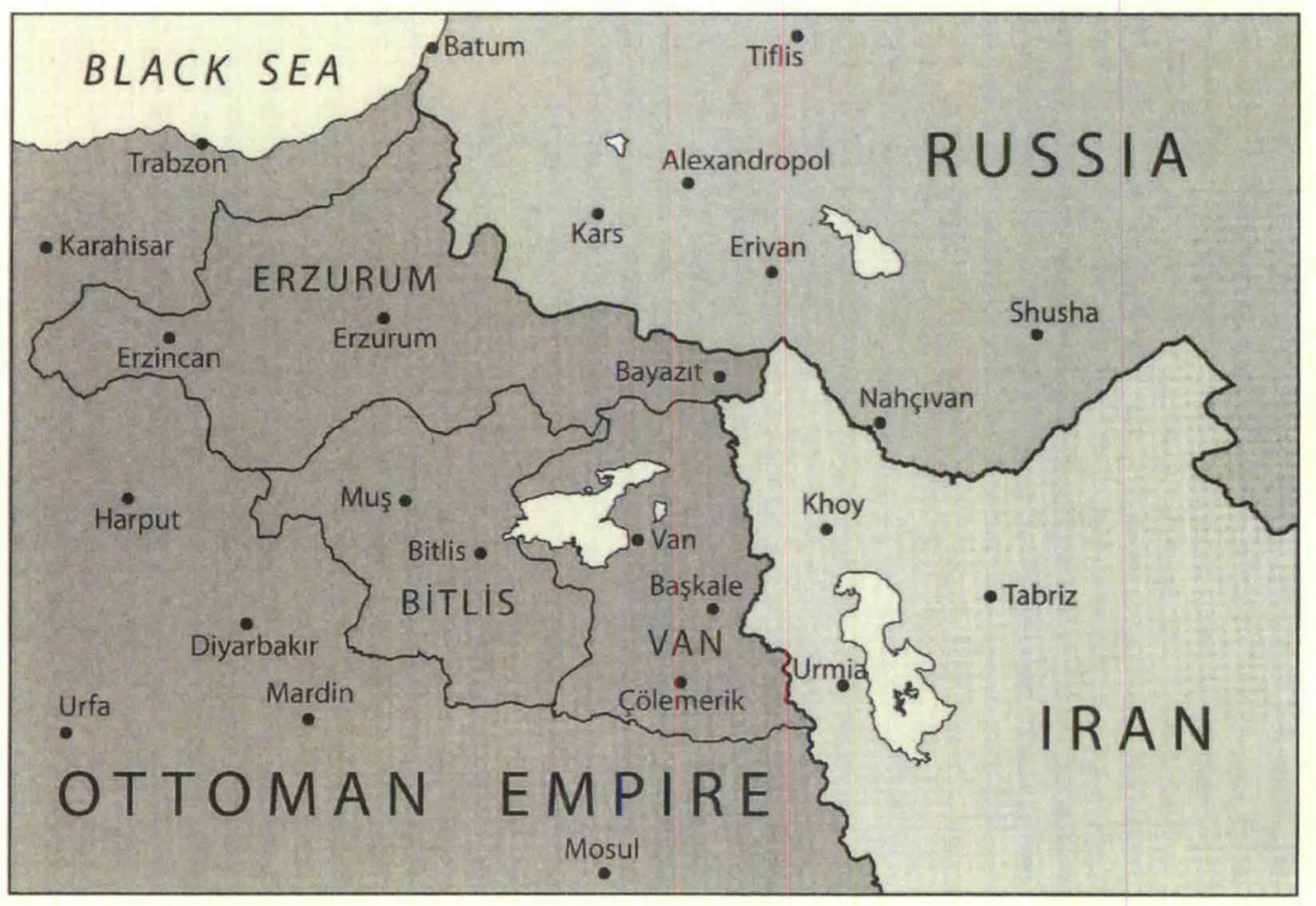

At the beginning of the twentieth century, the Armenians had established four local committees in Turkey. They had a base in Muş; propaganda and finance was handled through their bases at Trabazon and Erzerum, while their main headquarters were in Van. ${ }^{102}$ These bases that they had established acted as the backbone of the revolutionary network in crucial areas that would later be able to facilitate a Russian invasion. Their propaganda and fundraising efforts were perhaps the most overt, using reeducation in local schools, assassination and threats to encourage rich Armenians to

${ }^{100}$ Erickson, Ordered to Die, 97

${ }^{101}$ McCarthy, Justin. Ottoman Eastern Anatolia [map]. Scale not given. In: Justin McCarthy. The Armenian Rebellion at Van. Salt Lake City: The University of Utah Press, 2006, p. 8

${ }^{102}$ McCarthy, The Armenian Rebellion at Van, 87 
donate to the cause. ${ }^{103}$ McCarthy argues that "Many hated the revolutionaries and would have informed on their organization and weapons caches if they had not been afraid for their lives." ${ }^{104}$

Some Armenian committees, however, were afraid of the growing interest within the CUP for "Pan Turanism," which advocated the imposition of the Turkish language and culture on the subjects of the empire. The idea was a veracious Turkish nationalist pride that was intended to bring the Turkic world together under one banner facing heavy opposition from Europe. Erickson says that "In the Spring of 1914 the Turks intercepted letters from Armenian committees expressing concern over these developments. Other letters sent by the Dashnak [Tashnak] committee requested weapons from the Russians. $" 105$ The Russians did indeed send weapons and obviously expected Armenian acquiescence and assistance in the event of an Anatolian invasion. The Armenian committees would have been well aware of this fact, therefore any argument of selfdefense alone would be erroneous.

In a document from the Turkish archives known as the "Instructions for Personal Defense" dated 1910, the Armenian revolutionaries illustrate their aims on a village by village basis. According to the Ottomans, "tens of thousands" of copies were distributed. The document plainly states that there are three types of villages: "1) Those situated between other Armenian villages and exclusively inhabited by Armenians; 2) Those situated in non-Armenian zones, but nevertheless exclusively inhabited by Armenians; and 3) Those inhabited at the same time by Armenians and non-Armenians." Regardless of these distinctions, there was no difference in the organization of defense. The

\footnotetext{
${ }^{103}$ McCarthy, The Armenian Rebellion at Van, 88-90

${ }^{104}$ McCarthy, The Armenian Rebellion at Van, 91

${ }^{105}$ Erickson, Ordered to Die, 97
} 
document calls for the organization of detachments within each village comprised of two sections within each detachment - a "stationary force" and an "active force." In the "mixed" villages, the document calls for any enemies which might be the minority in relation to Armenians, to be "kept as hostages." In the last section of the document titled "To Attack Villages," there are several simple steps which must be adhered to in order to create the ideal conditions for attacking and overtaking an "enemy" village. Generalities apply in terms of basic guerrilla warfare such as having adequate intelligence, selecting a line of retreat, knowing the directional approach of enemy reinforcements should they come, attacking at dawn to maximize confusion and finally leaving any horses available that are not being used for mounted attacks to transport any casualties. ${ }^{106}$ It is the fourth point, however, which is particularly interesting and deserves to be quoted directly:

To attack the village only on three sides, leaving a side free for the besieged to make good their escape. (if the village is attacked on all sides, the enemy may fight with desperation and compromise victory.) However, on the side left free, a section of attackers must conceal themselves in order to pursue the enemy and cause him as much damage as possible. Furthermore, the object of leaving a side free is, rather than favor the retreat of the enemy, to break up his force of resistance and thus hasten victory; ${ }^{107}$

${ }^{106}$ McCarthy, The Armenian Rebellion at Van, 277-278

${ }^{107}$ McCarthy, The Armenian Rebellion at Van, 278 


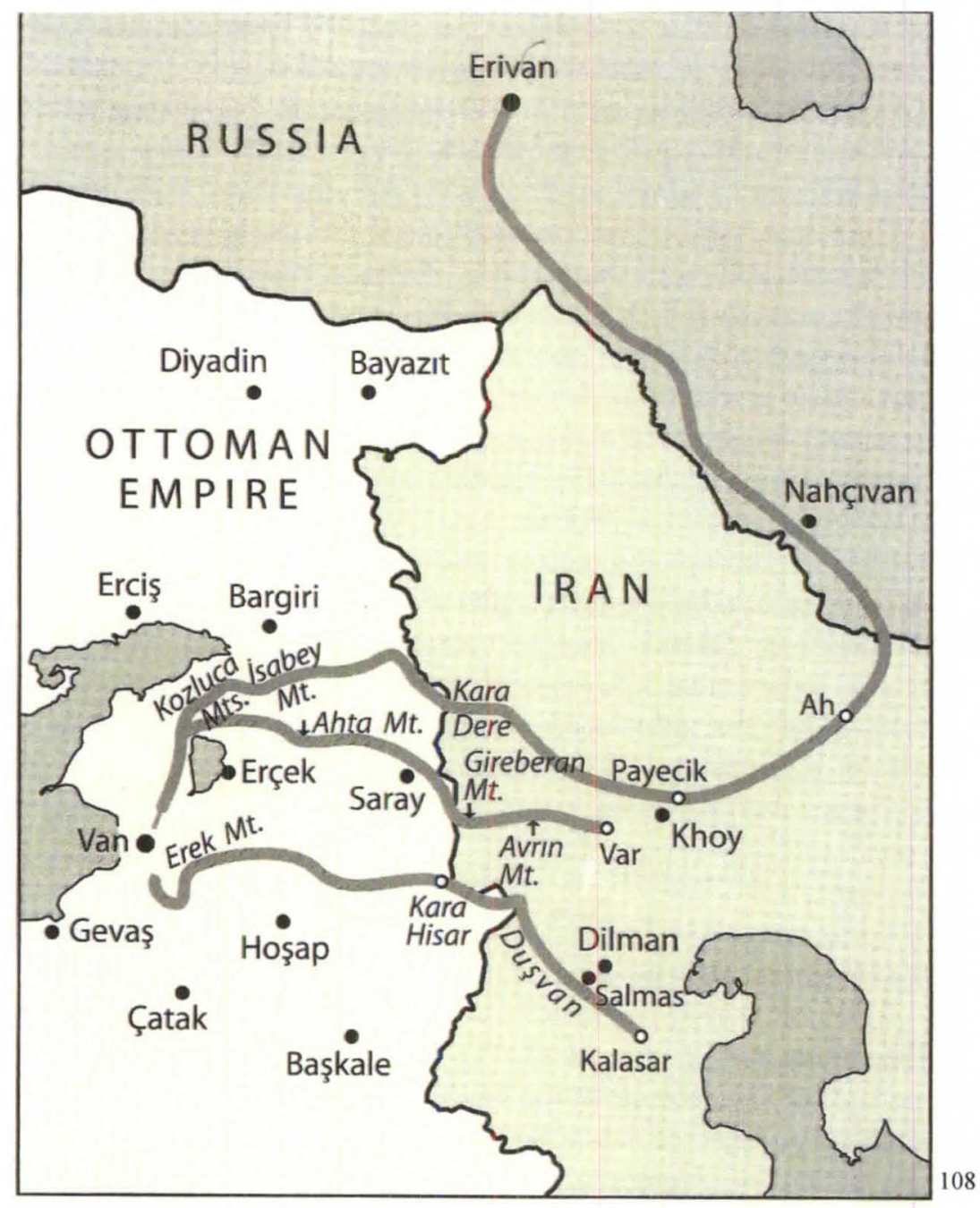

By the spring of 1914, the Armenian revolutionaries had already established intricate smuggling lines from Russia. Thanks to the Russian victory in the 1877-78 war against the Turks, the Russians had forced the Ottomans back from the previous territorial boundaries which ran along the Southern Caucus Mountains. Also, the Russian incursion into Northwestern Iran facilitated the perfect means for smuggling weapons from Russia directly into Ottoman territory and taking them to Van where the Armenian revolutionaries were conspiring with regular Russian forces. The Ottomans, realizing the growing threat of an Armenian revolt, patrolled their borders with Russia and Iran to

${ }^{108}$ McCarthy, Justin. Armenian Rebel Smuggling Routes [map]. Scale not given. In: Justin McCarthy. The Armenian Rebellion at Van. Salt Lake City: The University of Utah Press, 2006, p. 94. 
prevent such activities. In response, the Armenians used villagers and spies as their eyes and ears to report on troop patrols as well as Kurdish tribal movements. The use of Armenian spy networks is confirmed by an Ottoman $3^{\text {rd }}$ Army report to Turkish Commanders saying that "It is understood that they (Dashnaks) have set up espionage centers in Trabzon, Erzurum, Muş, Bitlis, Van, Sivas, and in Kayseri in order to inform the Russian Army about the movement and state of the Turkish Army."109 Once across the border with the weapons caches, the rebels would disguise themselves as Kurdish tribesmen and then village hop the weapons to their intended destination. ${ }^{110}$

Stockpiling continued as the Dashnak party grew stronger in the region bordering Russia and Iran. At the edge of the empire in the East, weapons were being gathered and Russian forces were training irregular fighters in preparation for a Russian invasion. ${ }^{111}$ From December of 1914 to March of 1915, the Armenian bands had begun to form themselves into regular units and were softening up the Ottomans for a Russian invasion. The rebels would disarm and overwhelm Muslim villages killing men, women and children indiscriminately, including Gendarmerie and soldiers. Most of the trouble was in Bitlis and Van, but by then, most of the eastern Anatolian countryside was at war and the Armenians were under Russian leadership. The war became one of Muslim and Armenian conflict, attack and counter attack, violence and revenge which was sparked by Armenians and exacted later by Muslims. ${ }^{112}$

As early as September of 1914, there had been reports of Armenian decent and concerns over the situation in the East as the situation grew more intense. One such report

\footnotetext{
${ }^{109}$ Turkey, General Staff Command, Arşiv Belgeleriyle şiirlerini Faaliyetleri 1914-1918 Cilt I, (Ankara: Genel Kurmay Basım Evi, 2005), 111

${ }^{110}$ McCarthy, The Armenian Rebellion at Van, 95-96

${ }^{11}$ McCarthy, The Armenian Rebellion at Van, 187-188

112 McCarthy, The Armenian Rebellion at Van, 194-195
} 
submitted by a police officer investigating the Bozviran village of Pasinler, just 25 miles

East of Erzerum, wrote in a report:

I have officially and unofficially had [sic] heard, when I was in Russia, that the Russian government was relying heavily on the Armenians for the solution of both the eastern provinces problem and for the solution of the minor upheavals in the Caucasus; and that the Russian government was trying to pull the Armenians on her side to incite upheavals and turmoil in the eastern provinces, Eastern Anatolia, whenever she wanted, with the aim of putting the pressure on our government by interfering with our internal affairs. I have also heard recently, in Petersburg, that the Russians's [sic] investing so much money for the realization of this goal has urged the Armenians living in our country to join the Armenians on the other side of the border who were already impelled by the Russians's [sic] behavior. Hence, I find the reports presented by the police extremely worthy of consideration; moreover, it can be asserted, without doubt, that most of the Armenians living in the eastern provinces are full of same [sic] desire and feeling. ${ }^{113}$

\section{The Van Insurgency and the Ottoman Response}

Having realized the full extent of the rebellion in the East, the Ottoman military tried to enforce the empire's policies. As previously mentioned, because of the lacking Gendarmerie in the region, there remained insufficient manpower to maintain a more stringent military code of conduct. The British and Russian offensives had drained nearly all regular Turkish forces and allocated them to the front lines, located in Eastern Europe. ${ }^{114}$ In April of 1915, Governor Cevat of Van, thinking that he could end the rebellion quickly, ordered the arrest of the leading members of the Dashnak party, assuming perhaps that he would fragment the revolt by removing its leadership. Ishkan, one of the more prominent leaders, left Van and was killed shortly after. Vramian, an effective party organizer in America, was arrested and "disappeared" before he reached Bitlis while under Ottoman guard. The leader, Aram Manukian, evaded Ottoman forces

\footnotetext{
113 Turkey, General Staff Command, Arşiv Belgeleriyle Ermine Faaliyetleri 1914-1918 Cilt 1, (Ankara: Genel Kurmay Basım Evi, 2005).29-30

${ }^{114}$ Erickson, Ordered to Die, 102
} 
and escaped. By the end of the month, an all out Armenian insurrection had begun with forces cutting telegraph lines and continuing to attack military personnel and civilians. ${ }^{115}$

McCarthy notes the importance of the fact that Armenian actions in preparation for the rebellion at Van had been made as early as October of 1914. This would indicate that based on Armenian Defense Council correspondence, the insurgency in Van had already been planning and preparing for war against regular Ottoman forces under the pretext of provocation. Haig Gossoian (Gassoyan) wrote of the Armenian preparations for war in Van under the leadership of the Armenian Defense Council. Gossoian recounted the preparations for a rebellion in Van by issuing a virtual "how to" guide to rural insurgency, months before the escalation of conflict in the region. Gossoian wrote:

In consultation with higher authorities, this council was able to complete essential tasks, such as, (a) registration of arms, preparation of arms caches and procurement of firearms, (b) registration of men fit for and capable of combat duty, appointment of defense leaders, reconditioning of arms, (c) creation of first aid and hospital facilities, and procurement of drugs, (d) and a provisioning committee, to be activated as soon as demand required. ${ }^{116}$

A document from the Ottoman archives dated September 13,1914, describes the information obtained during interrogations from several villages surrounding Erzurum. The document describes information that Loris Malko (Melikov), the son of a Russian General, had left for Van to incite uprisings. He had apparently been ordered "not to incite an uprising unless the Ottoman Army attacks [sic] Russia." The information continues saying that the Armenians of Van were instructed, "should the Ottoman Army declares [sic] war upon Russia, as usual, you are to incite an uprising; and if you enroll in

\footnotetext{
${ }^{115}$ McCarthy, The Armenian Rebellion at Van, 200
}

${ }^{116}$ McCarthy, The Armenian Rebellion at Van, 198 
the army, only one-third of you should join, and do not take part in the attacks against Russia." 117

Throughout April, the rebels paved the way for a Russian invasion into eastern Anatolia via Van, battling Kurdish irregulars who had been sent to fight. Where the Turkish government under the CUP (Committee of Union and Progress) had once attempted to negotiate with the Armenian revolutionary communities as a preventative measure, by the spring those methods proved "ineffective." 118 It was for this reason that the Ottoman government had initially attempted to relocate "... some Armenians who posed a threat," to Konya. This initial attempt at forced relocation in the east, however, proved ineffective as well because, according to Ottoman documents, these relocated Armenians believed to be a threat, soon joined with other revolutionary bands in the region southeast of Aleppo. ${ }^{119}$

In February of 1915, the Supreme Military Command of the Ottoman government circulated a warning to all units that Armenians were forming bands in various areas. The warning also said that Armenians were:

"...deserting from the army engaging in banditry, that large amounts of weapons and bombs had been found during searches, that these indicated that they were preparing for a rebellion and that to counter this threat the following measures were to be implemented: Armenian privates will not be employed in the mobile army and in the armed services, commanders will resist armed attacks, when necessary, they will declare martial law, a vigilant watch will be kept everywhere, searches will not be conducted in areas where there is no planned operation and loyal subjects will not be harmed in any way." 120

${ }^{117}$ Turkey, General Staff Command, Arşiv Belgeleriyle Ermine Faaliyetleri 1914-1918 Cilt 1, (Ankara: Genel Kurmay Basım Evi, 2005). 32

118 Turkish Republic Prime Ministry, Armenians in Ottoman Documents 1915-1920, (Ankara: Directorate of Ottoman Archives, 1995), 6

${ }^{119}$ Turkish Republic Prime Ministry, Armenians in Ottoman Documenis 1915-1920, (Ankara: Directorate of Ottoman Archives, 1995), 7

${ }^{120}$ Turkish Republic Prime Ministry, Armenians in Ottoman Documenis 1915-1920, (Ankara: Directorate of Ottoman Archives, 1995), 7 
As early as December of 1914, the Armenian rebels had been organizing themselves into bands along the Iranian border and various other places along the Ottoman border with Russia. Their command structure overall was one concentrated "loosely under Russian command." ${ }^{21}$ Throughout December, the Armenians approached from Iran with Russian support, while irregular bands were engaging in skirmishes and smaller battles with Ottoman forces. The main aim of the Armenian rebel bands was to cut the telegraph lines in order to prevent the Turks from maintaining effective communications with central command. Realizing this, Tahsin Bey, Governor of Erzerum, reported that there was a revolt within Van and other areas, and requested reinforcements to be sent. ${ }^{122}$

According to Ottoman documents, on April 24, 1915, a note from the Office of the Prime Minister to the Office of the Commander-in-Chief was sent detailing the appropriate actions to be taken in dealing with the uprising. The note stipulates that due to the activities of the Hunchak and Dashnak committee efforts, regions such as Zeytun, Bitlis, Sivas and Van were all posturing for revolt against the Ottoman Empire. The document continues saying that,

With the discovery of bombs, and the Ottoman Armenians' joining with the Russian forces by forming voluntary regiments against the Ottoman State, it has become evident that these committees...have gathered...in order to incite upheavals in the regions behind and to threat [sic] the Ottoman Army at every opportunity through their attempts, organizations, and publications. ${ }^{123}$

In light of these allegations, the note details the means by which the government intended to quell the rebellion by stating that they intended to close down the Hunchak and

Dashnak branches in both the capital and in various other provinces, seize any pertinent

\footnotetext{
${ }^{121}$ McCarthy, The Armenian Rebellion at Van, 192

${ }_{122}$ McCarthy, The Armenian Rebellion at Van, 193

${ }^{123}$ Turkey, General Staff Command, Arşiv Belgeleriyle şiirlerini Faaliyetleri 1914-1918 Cilt I, (Ankara: Genel Kurmay Basım Evi, 2005), 128
} 
documents, and arrest the committee leaders and members which had taken part in the activities. ${ }^{124}$ Due to previous attempts at appeasement, the gendarmerie and village police would have been well aware of who the members were and would have had no trouble identifying those believed to be responsible.

In March of 1915, most of the eastern Anatolian countryside was in turmoil and the fighting in Van province had intensified. The coming of spring meant the melting of snow and the opening of passes which would have previously hindered the Russian and Armenian volunteer advance from the Caucasus. McCarthy argues that perhaps the discovery of rebel plans by the Ottoman government may have hastened their pre-war planning process. ${ }^{125}$ This seems to be true because from a strategic standpoint, it would have made more sense for the Armenians to strike the city of Van while they were preoccupied with defense from a Russian invasion rather than try to take it themselves using smaller bands. Rebel attacks had begun with cutting telegraph lines, a tactic which they had been using regularly as a guerrilla maneuver to create chaos and prevent reinforcements in the region. By March, however, they had grown bolder, attacking military installations and gendarmes in the Armenian districts of Van. ${ }^{126}$ Çatak Kaza, (meaning "district"), was the site of the initial Armenian resistance, located in the southern area of Van.

Based on the investigations and interrogations of the gendarmerie, and the intelligence reports of the Ottoman $3^{\text {rd }}$ Army in eastern Anatolia, the Ottoman command

\footnotetext{
${ }^{124}$ Turkey, General Staff Command, Arşiv Belgeleriyle șiirlerini Faalivetleri 1914-1918 Cilt I, (Ankara: Genel Kurmay Basım Evi, 2005). 129

${ }^{125}$ McCarthy, The Armenian Rebellion at Van, 195

${ }^{126}$ McCarthy, The Armenian Rebellion at Van, 197
} 
was well aware of the situation in Van. A coded report to the Ottoman General

Headquarters states that,

As it was presented in the telegrams dated April 20 and 21 (1915), it has been decided that, without hurting the feeling of the people who obeyed the state, by making use of all the people who can be of help and by calling the men between the ages of 46 and 50 in military service, all the traitors who took ups arms against the state will be punished without showing mercy. If you would approve, I here by [sic] ask the conveying above-mentioned point to the Armenian Patriarch, who is charged with the duty of educating the people who go astray, and thus inspire the Armenians to obedience and loyalty to the state under his own leadership, rather than increasing the effects of the erroneous news of the traitor informers. ${ }^{127}$

It is essentially the issuance of a formal warning to be delivered to the Armenian community through the Armenian Patriarch. It is a warning meant to avoid the punishment of innocent people by proxy to the conflict in eastern Anatolia. A few days later (April 24, 1915), according to British Military Records, 1800 Armenians were detained by the Ottoman government from both the Hunchak and Dashnak parties as well as various other rebel volunteers. ${ }^{128}$

By May, when a mountain gun unit of the $28^{\text {th }}$ infantry and Mobile Gendarmerie battalions from Erzincan and Erzurum did arrive to reinforce the Ottoman forces, it was too late; the rebels had already gained a foothold in the region. The reinforcements did, however, manage to secure the only escape route toward Bitlis. ${ }^{129}$ Fighting continued, coordinated with Russian forces and on May 16-17, the remaining troops and civilians left the city. ${ }^{130}$ Aram Manukian was named governor of Van two days after the Russians entered the city on May 20, 1915, and the "Van Province Armenian Government" was

${ }^{127}$ Turkey, General Staff Command, Arşiv Belgeleriyle şiirlerini Faalivetleri 1914-1918 Cilt I, (Ankara: Genel Kurmay Basım Evi, 2005), 125

${ }^{128}$ Yusuf Halaçoğlu, The Story of 1915: What Happened to the Ottoman Armenians?, (Ankara:

The Turkish Historical Society, 2008), 42

${ }^{129}$ McCarthy, The Armenian Rebellion at Van, 212

${ }^{130}$ McCarthy, The Armenian Rebellion at Van, 215 
established. ${ }^{131}$ Forces sent to Van to quell the uprising were desperately needed to the East of the city to stop a Russian advance from the Caucasus, ultimately allowing rebel reinforcements to arrive and forcing the Ottomans out of Van. ${ }^{132} \mathrm{~A}$ media report of the Armenian victory at Van was published in the United States in Gochnak, an Armenian newspaper, which reported four days later, that only 1,600 Turks still remained in Van and that the rest had been expelled or slaughtered. ${ }^{133}$ Just one day after the Russians entered the City of Van, the Armenian revolutionary committee of Van received a telegram from Tsar Nicholas thanking them for their services to Russia.

The decision to evacuate the Armenian population was issued on May 26 by the Ottoman High Command to the Ministry of the Interior. It was suggested that all Armenians from the eastern provinces should be evacuated and also from similar places in Anatolia where Armenians were concentrated. The plan had been to move the Armenian communities further into the interior of the empire in order to eradicate subversive opposition from key strategic areas of Ottoman control. With three key points in mind regarding Armenian relocation, the Ottoman government made the decision to move the Armenians of Anatolia over 240 miles west of Van to an area south of Diyarbakır, near what is now the Syrian border. The three points were as follows: "1. the Armenian population should not exceed 10 percent of the tribes and Muslims in the area they were being relocated to; 2 . Each of the villages which the relocated Armenians would establish should not consist of more than 50 houses; and 3 . The evacuated

${ }^{131}$ McCarthy, The Armenian Rebellion at Van, 216

${ }_{132}$ McCarthy, The Armenian Rebellion at Van, 210

${ }^{133}$ Salahi Sonyel, The Great War and the Tragedy of Anatolia, (Ankara: Turkish Historical Society Printing House, 2000), 110 
Armenians should not be allowed to change their places of abode." $" 134$ This was obviously a concerted effort by the Ottoman government to prevent those forcibly relocated Armenians from causing any further trouble in their new homes. As stipulated by the directions for relocation, any disturbance would not have gone unnoticed.

As will be seen in the following chapter on the British in South Africa and the Americans in the Philippines, there were criminal acts committed in quelling insurgency at the military level. Talat Paşa wrote in his memoirs of this saying that those people who did take advantage of the situation were both "immoral" and "unscrupulous." In dealing out policy among the various political and military branches of the government, the Ottoman high command did issue contradicting orders which were perhaps confusing for some commanders. On the one hand they were ordered at the political level to "take the necessary measures" and at the military level they were ordered to "punish those who were responsible" while also being expected to protect the people. ${ }^{135}$ The issue of Armenian mistreatment in the forced relocations remains a hotly debated subject in Anatolian academia. Some claim that the Armenians were intentionally withdrawn from the east in an attempt to eradicate them by starvation and exhaustion through their grueling trek west, away from the battles. Research of the Ottoman archives, however, reveals that Talat Paşa himself signed orders stating that any officials found neglecting their duties and any civilian assailants were to be sent to Committees of Investigation and sent to martial law tribunal. ${ }^{136}$

\footnotetext{
${ }_{134}^{134}$ Sonyel, Tragedy of Anatolia, 113-114

155 Mim Kemal Oke, The Armenian Question 1914-1923, (Oxford: University Printing House, 1988), 135

${ }^{136}$ Yusuf Halaçoğlu, The Story of 1915: What Happened to the Ottoman Armenians?, (Ankara: The Turkish Historical Society, 2008), 84
} 
According to Yusuf Halaçoğlu, the Armenian delegation at the Paris Peace talks observed that there were as many as 180,000 Armenian volunteers who fought with the Russians from1914 to 1917 . Halaçoğlu continues saying, "German intelligence documents...state that as of February 1915, the French armed forces included a total of 12,466 Armenians, of whom 592 were Ottoman Armenians and 12,466 were Armenians from other countries." ${ }^{" 137}$ If claims such as this admitted to Armenian involvement in the Russian fight against the Ottoman Empire, then the threat from invasion was very substantial indeed. This figure also underestimates the number of Ottoman Armenians by not counting irregulars, a number that surely would have been much higher.

The Ottoman government took care in allowing the Armenians being forcibly relocated to bring whatever provisions they needed along with them. As the Armenians were relocated from areas of concern such as Van, Bitlis, Erzurum, Aleppo and Adana, the Ottomans also issued orders that the relocated villagers were to be counted and tracked from their point of origin to the village they were being relocated to. ${ }^{138}$ This was done with the intention of allowing Armenians to return to their homes at war's end, otherwise the entire process seems costly and redundant. On securing the civilian population, the current U.S. coalition counterinsurgency doctrine states:

The field manual directs U.S. forces to make securing the civilian, rather than destroying the enemy, their top priority. The civilian population is the center of gravity the deciding factor in the struggle. Therefore, civilians must be separated from insurgents to insulate them from insurgent pressure and to deny the insurgent 'fish' the cover of the civilian 'sea'. By doing so, counterinsurgents can militarily isolate, weaken, and defeat the insurgents. ${ }^{139}$

\footnotetext{
${ }^{137}$ Yusuf Halaçoğlu, The Story of 1915: What Happened to the Ottoman Armenians?, (Ankara: The Turkish Historical Society, 2008), 32-33

${ }_{138}$ Turkish Republic Prime Ministry, Armenians in Ottoman Documents: 1915-1920, (Ankara: Directorate of Ottoman Archives, 1995), 36-39

${ }^{139}$ The U.S. Army and Marine Corps Counterinsurgency Field Manual, (Chicago: University of Chicago Press, 2007), xxv
} 
From a strategic standpoint, the relocation of a potential insurgent force was more than a difficult decision; it was believed to be a tactical necessity. It would have been literally impossible for the Ottomans, or any other military force then and now, to tell an insurgent from a civilian at a glance. Age and gender are obvious indications of insurgent potential but that designation can only be very generally applied to soldiers. It does not account for insurgent support bases that can be found within a civilian population. Therefore, in order to remove an imperceptible threat from a sea of indistinguishable enemies the only alternative was to drain the sea to remove the threat; a suggestion which was apparently at the behest of German advisement. ${ }^{140}$ Given the state of the Ottoman Empire at the time, their struggle was not one of colliding titans. Theirs was a struggle of survival, for the continuity of the empire. It was also a proven measure which had been used by their British and American counterparts over a decade earlier which will be discussed in the next chapter.

Halaçoğlu argues that if one is to accept the estimates of Armenian losses in Anatolia, Syria and the Caucasus, then casualties "would have been around 250,000 to $300,000 . "$ He also argues, however, that most of these deaths were the result of epidemics, which in other European countries of the same time period, were also very high - a problem which also plagued the Filipino community over a decade earlier, following the civilian relocation efforts of American forces. According to Halaçoğlu's calculations, from 1918-1920, Britain had an estimated 167,805 deaths, France had an

${ }^{140}$ Yusuf Halaçoğlu, The Story of 1915: What Happened to the Ottoman Armenians?, (Ankara: The Turkish Historical Society, 2008), 43 
estimated 137,173 deaths, and Germany had an estimated 247,983 deaths - all of which were epidemic related. ${ }^{141}$

The Turks have received the most criticism for the Armenian death rate during this period because of their decision to relocate large numbers of the Armenian community for reasons of security. Critics draw their arguments from demographic figures which also happen to be in the areas of greatest contention in the east from Armenian rebels: Erzurum, Bitlis and Van. According to McCarthy, perhaps the greatest argument for the survival of Armenians in this region is also demographic, mainly from the number of Erzurum refugees. McCarthy says that, based on the 1897 Russian census there were approximately 1,161,909 Armenians in the Caucasus region.

Due to natural increases in population, by 1914 the population should have been around $1,444,000 .^{142}$ The men were at war in the Caucasus during World War I so it can be assumed that by 1917 the population statistics would have been about the same. Of the Armenians in Ottoman Anatolia, the total population from Erzurum, Van and Bitlis in 1912 was about 485,000 . Based on official Russian sources quoted by Richard Hovannisian for the Armenian population of the Caucasus in 1917, the total number listed was $1,783,000$. Subtracting $1,444,000$ from $1,783,000$ leaves 339,000 - this means that the extra 339,000 must have come mostly from Ottoman Anatolia. ${ }^{143}$ These refugees would have been subject to the cold, dying mostly from starvation and disease.

${ }^{141}$ Halaçoğlu, The Story of 1915, 68-69

142 Justin McCarthy, "The Destruction of Ottoman Erzurum (Osmanlı Erzurum Tahribatı)", (Erzurum: Ankara Üniversitesi, 2002,) 4, author's manuscript copy

143 Justin McCarthy, "The Destruction of Ottoman Erzurum (Osmanlı Erzurum Tahribat1)", (Erzurum: Ankara Üniversitesi, 2002,) 4, author’s manuscript copy 
The Turks later regained the city, forcing the Armenians of the region to follow the Russians in their retreat expecting asylum. Once the Russians retook the city of Van in September of 1915, and defeated the Turks at Köprüköy in January of 1916, Russian dominance in the East was assured. The Armenians believed that they would be allowed to return to their homes following the Russian victory in the East, yet the Russians would not allow it, putting the entire region under the command of a military governor. ${ }^{144}$ It was a result that the Armenians did not expect having previously arranged an agreement that the area taken in the east by the Russians would become an Armenian nation of the Russian Empire. ${ }^{145}$ Of the Armenians that remained, many of those who joined forces with the Russians had already been a part of the Armenian resistance in the East.

Ottoman and Russian Armenians, as well as Armenian deserters from the Ottoman army, were among them leading the Russian forces moving further west, deeper into Ottoman territory on the offensive.

Salahi Sonyel, wrote about the irregular Armenian groups that operated under Russian control and the aftermath of the rebellion at Van. Sonyel wrote:

The atrocities committed by the Armenian volunteer forces accompanying the Russian army were so severe that the Russian commanders themselves were compelled to withdraw them from the battle fronts and employ them in the rearguard duties. The memoirs of many Russian officers, who served in the East at this time, are full of accounts of atrocities committed by these Armenian guerrillas, which were savage even by the relatively primitive war standards then observed in such areas. ${ }^{146}$

What is remarkable about this statement is that many of the irregular forces operating under Russian command were generally supported by Cossack regiments in irregular

\footnotetext{
${ }^{144}$ McCarthy, The Armenian Rebellion at Van, 242

${ }^{145}$ Turkey, General Staff Command, Arşiv Belgeleriyle şiirlerini Faaliyetleri 1914-1918 Cilt I, (Ankara: Genel Kurmay Basım Evi, 2005), 109

${ }^{146}$ Sonyel, Tragedy of Anatolia, 111
} 
operations. The Cossacks were known for their uncompromising brutality and their skill and application in unconventional tactics. The fact that Russian officers' testimony of the Armenian irregulars brutality was worthy of noting is compelling when considering the source.

McCarthy says, "Of the original 575,000 Armenians in the four provinces, 339,000 survived when the fighting ended, a mortality rate of 41 percent." Regarding the Muslim population it is important to quote him directly:

"Muslim mortality was statistically worse, although the disaster for both peoples was so great that such comparisons have little meaning. Of the 313,000 Muslims who had lived in Van before the rebellion and war, only 1 19,000 were present at war's end. The other 194,000 (62 percent, nearly two-thirds) had died." ${ }^{147}$

It is obvious that everyone in the region had suffered tremendously on both sides of the conflict. Although, the civilians had taken the brunt of the atrocities as they generally do in wartime. McCarthy also says that:

"During the Russian invasion and after Van City had fallen, the Armenians set about ridding the province of Muslims. Despite the flight of refugees, a sizable Muslim population still remained in the villages. Attacks on Muslim villages had been limited by the speed of the Russian and Armenian advance. Once the province had fallen, however, the attacks increased and became methodical. They followed a constant pattern: wounded and sick Muslim soldiers...were always among the first to be killed, along with any officials or religious leaders. Where adult males were present, the men and young boys were taken away and killed. In some villages the women were then raped and sometimes killed." 148

Aside from the obvious reasons for relocation and the security of the people of the region, whether it was Muslims from Armenians or Armenians from Muslim reprisals, there are other more technical reasons for their relocation. From a counterinsurgency standpoint, it would have been vital to the Ottoman war effort to secure their lines of communication. Armenian insurgents recognized this fact which is why among the many

\footnotetext{
${ }^{147}$ McCarthy, The Armenian Rebellion at Van, 246

${ }^{148}$ McCarthy, The Armenian Rebellion at Van, 238
} 
guerrilla tactics that they utilized, cutting the Ottoman lines of communication was one of the most effective. Sonyel argues that, "the possibility of widespread rebellion behind Ottoman lines, and of the danger of the Ottoman army having to fight on a number of fronts, with its lines of communication threatened, compelled the Ottoman government, on 24 April, to decide to remove the Armenians from vulnerable strategic points where they could assist the enemy.",149

There was no existing counterinsurgency doctrine in the Ottoman Empire at that time; therefore, there are no clear indications of its application in documentary evidence. There is, however, enough evidence to suggest that the Ottomans were greatly concerned with the protection of supply and communication lines through the use of intelligence and the relocation of civilians. Due to the poor roads and lines of communication, it would have been essential for the Ottomans to secure these aspects of military defense in eastern Anatolia. Without the protection of this region and its strategic vulnerability based on its proximity to the Russian border, an all out Russian invasion of eastern Anatolia would have been imminent. Indeed, the Russians did invade Anatolia as they had many times before. With the help of Armenian insurgents within the Ottoman Empire, the Russian invasion of Anatolia during World War I was aided by Armenian insurgents and posed a clear threat to the continuity of the Empire.

${ }^{149}$ Sonyel, Tragedy of Anatolia, 113 


\section{CHAPTER IV}

\section{THE WESTERN WORLD AND THE COUNTERINSURGENCY EXPERIENCE PRIOR TO WORLD WAR I}

“On occasion it may be necessary to move or resettle civilians, because such action is urgently required for military activities. Under no circumstance do you burn civilian property without approval of higher authority. Similarly you do not steal from civilians. Failure to obey these rules is a violation of the laws of armed conflict and punishable by court-martial.

-United States Marine Corps, Guidebook for Marines, 2001

\section{British South Africa and the Anglo-Boer War}

By 1899 , at the outset of war with the Boers, the British already had experience defending the honor of the Crown in their colonies abroad. The war with the Boers seems to have been little more than a combination of repairing a wounded ego and securing commercial opportunities in the region, mainly from diamonds and gold. South Africa was formerly a Dutch colony until 1795 when a republic replaced Holland's royal government, a change which was inspired by the French. England was handed the reins of Dutch colonies by the Prince of Orange in the hopes that one day Holland could regain its colonial possessions. Until that point, South Africa had been under the control of the Dutch East Africa Company for 143 years. Although trouble mounted throughout the subsequent decades following British control, it was this transfer of power that fueled the fires of discontent for colonial rule within the Boer collective.

\footnotetext{
${ }^{150}$ United State Marine Corps, Guidebook for Marines, (Quantico: Marine Corps Association, 2001), 44
} 
The Boers, meaning "farmers" (also called Afrikaners), were the multinational result of years of migration to the region from a number of European countries. Settlers from Holland, France and Germany constituted the majority of the population in the early years of the republics. Boers, like most colonial settlers, were rugged, strong willed people forged through years of adaptation in harsh territory. Since the beginning of the regions' settlement in 1652, the Boers struggled to carve a life for themselves in their new African homeland. As is the case with most colonial settlements, the natives, or Hottentots (now known as the Kohekohe), of the region were the first to feel the effects of European colonialism. European settlement inevitably meant violent clashes between the two groups as the settlers pushed further into the interior, conflict, and ultimately subjugation of the indigenous Kohekohe by the Boers. ${ }^{151}$

The Boers were, as their name implies, farmers of South Africa. Much like their American cousins, the value of slave labor was soon realized, though the source of indigenous personnel required to fill the position was readily available. The Kohekohe were the primary source of indigenous labor utilized by the Boers after their continued conflicts proved that the Boers were not going anywhere. When the British took control of the African colony, they saw the Boer's relationship with the natives as a violation of humanity. According to Byron Farwell, "British concepts of justice and humanity conflicted with those of Britain's truculent white South African subjects. From the beginning, her policies were designed to protect what she regarded as the interests of the natives and to prevent the abuse of slaves and Hottentot servants, who often lived in a state close to slavery."152

\footnotetext{
${ }^{151}$ Byron Farwell, The Great Anglo-Boer War, (New York: Harper and Row Publishers, 1976), 4

152 Farwell, Anglo-Boer War, 5
} 
It was, of course, a noble gesture of royal colonial integrity. For the Boers, however, British meddling in African affairs was a gross breach of relative autonomy. This was especially infuriating for the Boers considering that the South African economy was primarily based on slave labor. ${ }^{153}$ Reforms under British law followed over the next thirty years (1795-1828) granting more rights to the indigenous Kohekohe and removing the shackles of indignity in South African farming culture. The reforms were a tremendous source of tension between the Boers and the British, eventually resulting in one notable skirmish which is still remembered to this day as "The Hanging at Slachter's Nek." The hanging was a public display of British supremacy when five men were executed after a failed revolt of sixty men against the British. The revolt was a reprisal for killing a Boer farmer named Bezuidenhout ${ }^{154}$ who resisted arrest for failure to acknowledge several court summons. Bezuidenhout was hailed a hero and the five men executed became martyrs for a cause. ${ }^{155}$ Conflict with the British became even more likely when, in 1833 , slavery was abolished throughout the Empire.

By December 1, 1834, all of the 39,021 slaves of the South African colony were to be emancipated under the new British law. This meant that a great many farms would eventually go under due to their dependence on slave labor. Compensation was promised by the British government with more that $£ 3$ million expected (about $\$ 101.9$ million today), though only about $£ 1.2$ million was actually provided for reimbursement, which

${ }^{153}$ Farwell, Anglo-Boer War, 6

${ }^{154}$ Frederick Cornelius Bezuidenhout was killed in 1815. Bezuidenhout refused to appear for three court summons to answer for claims of mistreatment of his servants in what the Boers called "Black Court." Bezuidenhout was approached at his farm by a Lieutenant and twelve Hottentot police. Upon their arrival, he fired at the police and in turn was killed. The incident was used as an excuse to incite a revolution of sixty men, led by his brother. Forty seven of the men were captured, thirty banished and six sentenced to be executed, though one was later pardoned. (See Farwell, Anglo-Boer War, 5)

${ }^{155}$ Farwell, Anglo-Boer War, 5 
was payable in London. ${ }^{156}$ From this, it is evident that based on the rugged nature of the Boer community being similar to that of the American frontiersman, attempts at colonial control and restrictions in unsettled territory would inevitably be met with resistance. It would seem that such attempts at control by a distant empire, offering what appeared to be very little assistance in return for obedience, would ultimately be met with rebellion. Even though the logic behind intervention was sound and the abolishment of slavery a utilitarian judgment, the Boers surely could not have been expected to simply accept it.

\section{Boer Displacement and Relocation}

Tensions finally came to a head in October of 1899 , when the Anglo-Boer War finally began. Negotiations had failed on numerous occasions and appeals for peace and reconciliation went virtually unheard. The British, prior to the declaration of war with the Boers, had suffered notably humiliating defeats at Gorbler's Farm ${ }^{157}$ and Majuba. ${ }^{158}$ It is necessary to illustrate the significance of Majuba in order to portray the importance it had in the minds of both the British and the Boers leading up to the war. Farwell writes:

Majuba, although a small affair, was particularly mortifying for Britain; never before in its long history had British arms suffered such a humiliating defeat: a group of unsoldiery farm boys had completely routed a British force containing elements of the Royal Navy and regulars from some of the most famous regiments in the British army, and a force, moreover, that was six times larger than that for the Boers and in what ought to have been an impregnable position."159

${ }^{156}$ Farwell, Anglo-Boer War, 6

157 The incident at Gorbler's farm was a surprise attack on a British regiment scouting for Boer resistance. The result was a warning issued by the Boers to the British regiment of immediate surrender or be killed. The British refused and the Boers opened fire, killing 56 soldiers, 1 woman, and wounding 101 , of which 20 later died.

158 Under cover of darkness, British forces had gained the high ground in order to surprise the Boer forces and defeat them with tactical superiority in every way. The result, however, was the humiliating defeat of the British force, the death of the unit commander and the retreat and capture of countless British soldiers. (See Martin Meredith, Diamonds, Gold, and War: The British, the Boers, and the Making of South Africa, (New York: Public Affairs, 2007), 95-104

${ }^{159}$ Farwell, Anglo-Boer War, 19 
Perhaps the most important incident, however, was the failed coup d'état in 1895. British immigrants from the gold rush and mine owners, including Cecil Rhodes, the prime minister of Cape Colony, attempted to overthrow the Boer government in favor of British rule. The coup was a complete failure and yet another embarrassing blow to the British ego. ${ }^{160}$

The Boers were some of the finest marksmen in the world, able to judge distance easily based on an intimate knowledge of the landscape. This was undoubtedly the result of their lifestyle in the Transvaal, an area northeast of their previous homeland before the British abolished slavery. The men of the Transvaal were rugged just as their forefathers were; however, they had developed an even greater sense of independence the further they had moved from British control. ${ }^{161}$ This surely contributed to their use of guerrilla tactics when they fought the British during the war.

The first year of the war (1899) had not gone according to plan for the Boers. Sieges in major cities such as Ladysmith, Mafeking and Kimberley made a British victory nearly assured because they had gained territorial superiority over the Boers in defense of the Transvaal. Due to their losses in the Transvaal, the Boers began the second phase of the war, adopting guerrilla tactics to which they were better suited. Their skills with the more advanced, clip fed, Mauser rifle - coupled with their talents as horsemen made the Boers a formidable foe during this new phase of warfare. ${ }^{162}$ The Boers began to

${ }^{160}$ Kiras, "Irregular Warfare, “ 247

${ }^{161}$ Farwell, Anglo-Boer War, 15

${ }^{162}$ The Mauser Rifle was the only piece of equipment which was provided by the Boer government to their volunteers. The rifle was far better suited to their needs than the British Lee-Metford and Lee-Enfield rifles that had been issued to their regulars. The Mauser was a five round, magazine-fed weapon where the Metford and the Enfield were loaded individually. This meant that while the two opposing soldiers could fire five rounds at the same speed, a Boer commando had a much greater rate of fire than a British soldier with successive shots. Not to mention that the Mauser was far more accurate than 
utilize their knowledge of the landscape and their affinity for surprise attack to make trouble for the British forces. They struck without warning by destroying trains, railways, bridges and attacking small convoys and garrisons. They also used sniping to their advantage rather than direct conflict with the enemy as they had done the previous year. $^{163}$

Alexander Downes wrote that there are two uses of civilian victimization which can be used to defeat an insurgency. One is by targeting noncombatants in order to deter others from supporting the enemy forces. The other is by severing the civilian support base from guerrilla access. Downes argues that, "In this scenario, incumbents either kill or relocate large numbers of civilians in order to make it physically impossible for the insurgents to obtain food, shelter, recruits, or intelligence from the people."164 The success of such methods obviously does not justify their use. What Downes is trying to point out is the crucial role that civilians play in determining control, either for the insurgency or counterinsurgency.

It was the British difficulties in combating the Boer guerrillas which led to international criticism of their decisions. Because of the Boer's mobility, which was fast and agile compared to the slow movements of British troops, it was impossible to keep up with them. The British had to be everywhere at once, and the Boers were able to strike wherever they pleased at will. Because of this, the British chose to deny the Boers their source of support within the civilian community. This meant the burning of farmsteads to

the British Metford and Enfield rifles. This was mostly the result of poor preparation on the part of the British, the Metford and Enfield rifles had been poorly sited before they reached the soldiers. Not to mention the fact that the British were unaccustomed to the South African landscape, making the judgment of distances very challenging. (see Farwell, Anglo-Boer War, 43)

${ }^{163}$ Farwell, Anglo-Boer War, 324 $157-158$

${ }^{164}$ Alexander B. Downes, Targeting Civilians in War, (Ithaca: Cornell University Press, 2008), 
deny passing commando units' food, the construction of blockhouses and the resettlement of the civilian population into camps. ${ }^{165}$

The Boer commanders knew that direct action against the British in the form of regular warfare was no longer an option by 1900 . Simultaneously, the British realized that the Boers were headstrong, not to give in so easily after only one year of fighting the Empire. Therefore, it was decided on September 22, 1900 that camps would be constructed for the Boers who wished to surrender voluntarily and submit to British protection and control within these camps. By December 21, 1900, it was realized that there were significant advantages to herding civilians into these camps, both with their consent and against their will, in order to combat the guerrilla threat from the Boer commandos. Farwell wrote that, "More Boer boys and girls under the age of sixteen died in British concentration camps than all the fighting men killed by bullets and shells on both sides in the course of the entire war."166

Between December of 1900 and February of 1902, within the fifty or so camps that had been constructed, there were around 160,000 Boer inmates total and about 130,000 Africans. ${ }^{167}$ By war's end, of the approximate 160,000 inmates about 27,927 Boers had died in the camps, mostly attributed to disease and starvation. This left the camps with a 17 percent fatality rate of the total number of incarcerated civilians. The fatality rate of women or children under the age of sixteen was 94 percent, according to Downes figures from André Wessels. ${ }^{168}$ The technique proved to be effective because by removing the civilians from the field of battle, which in the case of the Transvaal and

\footnotetext{
${ }^{165}$ Kiras, "Irregular Warfare," 248

${ }^{166}$ Farwell, Anglo-Boer War, 392

${ }^{167}$ Downes, Targeting Civilians in War, 160

${ }^{168}$ Downes, Targeting Civilians in War, 161
} 
Cape colony could have been anywhere, meant that the civilians could not support the guerrillas, voluntarily or otherwise. British soldiers also burnt farms and killed livestock to remove the source of support for the roaming guerrillas; a tactic most famously employed by the Russians to prevent the advance of Napoleons army into Russia.

British forces made use of the extensive blockhouse system in order to choke and isolate enemy movements across the open region. The British increased their patrols and protection of supply lines, further removing guerrilla potential for attack and a means of supply. ${ }^{169}$ Strangling the Boers into submission was indeed a well adapted process. Perhaps the most effective technique, however, was the use of concentration camps in order to deny the guerrillas a crucial support base. The table below illustrates this point by recording a rise in the number of civilians interned gradually throughout the final phase of the war.

TABLE 4.1 British Population Statistics for Civilian Relocation Camps ${ }^{170}$

\begin{tabular}{|c|c|c|c|c|}
\hline \multicolumn{3}{|c|}{ Camp Population } & \multirow{2}{*}{$\begin{aligned} & \text { Deaths } \\
& 777\end{aligned}$} & \multirow{2}{*}{$\frac{\text { Blue Book }}{\text { I7l }}$} \\
\hline 1901 & June & 85,410 & & \\
\hline & July & 93,940 & 1,412 & Cd 694 \\
\hline & August & 105,347 & 1,878 & Cd 789 \\
\hline & September & 109,314 & 2,411 & Cd 793 \\
\hline & October & 113,506 & 3,156 & Cd 853 \\
\hline & November & 117,974 & 2,807 & $\mathrm{Cd} 934$ \\
\hline & December & 117,017 & 2,380 & $\mathrm{Cd} 902$ \\
\hline \multirow[t]{5}{*}{1902} & January & 114,376 & 1,805 & $\mathrm{Cd} 934$ \\
\hline & February & 114,311 & 628 & $\mathrm{Cd} 939$ \\
\hline & March & 111,508 & 402 & Cd 939 \\
\hline & April & 112,733 & 298 & $\mathrm{Cd} 942$ \\
\hline & May & 116,572 & 196 & $\mathrm{Cd} 1161$ \\
\hline
\end{tabular}

${ }^{169}$ Farwell, Anglo-Boer War, 350

${ }^{170}$ Farwell, Anglo-Boer War, 408

171 The Blue Book was a series of documents meant to rebut claims of inhumanity from the international community. Each number refers to a document which is meant to be an accurate portrayal of the conditions and population figures of the camps throughout the war. 
The table shows a noticeable increase in the number of interned civilians in the British camps. The interned would, as previously stated, have been members of the local communities viewed as a threat to British supremacy and control of the region. Coupled with the rise in civilian interned there is a noticeable rise in the number of deaths as well. This was mainly the result of overcrowding. Overcrowding led to unsanitary conditions and ultimately the rapid spread of disease. The conditions of the camps would have been the responsibility of the British government, though the result was that they were unwilling to provide adequate services and supplies to the civilians within the camps, mainly in an effort to save money.

Lord Kitchener, the man who took control of British armed forces in the second phase of the Boer War, admitted in June 1901, that one of the other reasons for creating the camps was to coax the Boer commandos into submission by creating a strong desire to be with their families. ${ }^{172}$ At first, there had been a preferential treatment system regarding the issuance of rations to the interned civilians of the camps. The people who had voluntarily surrendered to internment were given more food while those who were forced received less. According to a prison doctor, the voluntary inmates maintained a diet which was "deficient in fats and phosphates," and that those who had been interned maintained a diet which was "not consistent with the maintenance of health for any lengthened period."173

British statistics from Blue Book documents differ with more recent statistics, including the large number of African civilians which also died as a result of internment

\footnotetext{
${ }^{172}$ Godfrey. H. L. Le May, British Supremacy in South Africa 1899-1907, (Oxford: Clarendon Press, 1965), 96

${ }^{173}$ Le May, British Supremacy, 97
} 
and the scorched earth policy adopted by the British throughout the guerrilla phase of the war. The number of civilians killed is obviously a daunting prospect and a stain on British history, yet what is important here is the camps application as a measure of success in warfare. What is also important to recognize is the effectiveness and success of a guerrilla or insurgent fighting force and the extreme measures necessary to overcome them. The table below shows the relative application of military forces and their success. In the first phase of the Boer war, the Boers utilized conventional tactics with unconventional regimental structure with greater manpower and they were quickly overwhelmed. When they adopted guerrilla tactics in 1900 , however, they were able to hold out for another two years against the British, even with a smaller fighting force.

The numbers speak for themselves showing that, by isolating the civilian population from the Boer resistance, the British were able to choke the Boers into submission. The British denied the Boers both emotional and strategic support by using the civilians as the center of gravity, turning the Boers greatest weapon of resistance against them. The will to fight the British would have been strong indeed, though perhaps the will to protect ones family and means of survival was stronger.

TABLE 4.2 Manpower and fatalities of the Second Anglo-Boer War ${ }^{174}$

\section{British}

20,000

Manpower at start of war

Fielded forces, end 1900

Total manpower employed

Military fatalities

Civilian fatalities

Total war deaths
200,000

478,435

21,942

NA

21,942

\section{Boers}

55-60,000

20,000

87,365

6,189

27,927

34,116

\footnotetext{
${ }^{174}$ Downes, Targeting Civilians in War, 164
} 


\section{Southeast Asia and the Philippine-American Conflict}

The Philippine-American conflict was fought in a way very similar to how the British handled South Africa. Like the Anglo-Boer war, it consisted of two stages against an indigenous population seeking the removal of a foreign enemy in favor of gaining independence. The battle for the Philippines was first fought against the Spanish Empire in 1897 , who at the time, maintained control over the archipelago. Later, United States involvement followed after the Spanish American war of 1898. At the forefront of the rebellion was the secret organization known as the Katipunan society ${ }^{175}$, which had attempted an insurgency during August of 1896. The failed attempt at insurrection resulted in the use of guerrilla tactics. Emilio Aguinaldo became the main leader of the movement due to the notoriety he gained fighting the Spanish. Despite their efforts to remove the Spanish from the Philippines, Aguinaldo was forced into exile in exchange for a promise that the Spanish empire would concede new democratic reforms under their continued control of the region. Unfortunately, once Aguinaldo left, the Spanish quickly forgot the promises that they had made. ${ }^{176}$

Though Aguinaldo was hailed as a competent organizer regarding the Filipino resistance through the Katipunan, he failed to develop as a military strategist and field

\footnotetext{
${ }^{175}$ The name Katipunan refers to the organization under Andres Bonifacio. Based in Manila, the organization stood for the "Highest and Most Honorable Society of the Sons of the Country." It was a secret organization, bathed in mystique and societal rituals, compiling "revolutionary rhetoric" and nationalist idealism, as well as Tagalog ethnocentrism. The society ultimately sought complete independence from Spain, even if it meant armed insurrection. Though the organization had widespread success, it was mainly limited to the area of Manila and was plagued by tribal rivalries, also lacking sustainable cohesion. This would later be a problem solved by Emilio Aguinaldo. (See Brian M. Linn, The U.S. Army and Counterinsurgency in the Philippine War, 1899-1902, [Chapel hill: The University of North Carolina Press, 1989], 4)

${ }^{176}$ John Ellis, From the Barrel of a Gun: A History of Guerrilla, Revolutionary and CounterInsurgency Warfare, From the Romans to the Present, (London: Greenhill Books, 1995), 132
} 
commander. His background in politics and inter-island business dealings had been the source of his recognition and initial success within the communities. His ability to hold the irregular forces together to fight the Spanish is what set him apart as a leader. ${ }^{177}$ The United States had been fighting the Spanish in 1898 at the same time that Filipino revolutionaries were attempting to seize control of the islands through insurgency and guerrilla tactics. Because of his standing within the community, primarily the Tagalog provinces, Aguinaldo was an ideal candidate for the leadership of indigenous troops and what was intended to be a smooth governmental transition. Aguinaldo, unaware that the transition of leadership was intended to be one from Spanish to American, was supportive of American forces taking control of Manila with the assistance and support of his irregulars. Although, Aguinaldo and the U.S. (American Consul E. Spencer Pratt) were suspicious of one another's motives once victory over the Spanish was attained. ${ }^{178}$

If attempts at understanding this transitional period - from a Filipino-American coalition against the Spanish to a Filipino-American conflict - seem difficult, it is because they are. Realistic interpretations of the source of conflict are hard to come by. The Americans were suspicious of the Filipinos, fearing that they might attempt to take control of Manila, and were determined to be independent. Comparatively, Filipinos were suspicious of American intentions once they had defeated the Spanish in Manila. Both assumptions proved to be correct no matter how one views this particular aspect of history from 1898-1899 in the Philippines. As Brian Linn argues, "the circumstances surrounding the outbreak are still matters of strong dispute. The actual events are still unclear, as is the much larger issue of who, if anyone, was responsible for starting the $19-20$

${ }^{177}$ Brian M. Linn, The Philippine War: 1899-1902, (Lawrence: University Press of Kansas, 2000), ${ }^{178}$ Linn, Philippine War, 20-22 
war." ${ }^{\prime 179}$ As is the case in virtually all warfare, and especially in the cases of the aforementioned conflicts within this thesis, each side inevitably blames the other for being the catalyst to open conflict.

What is clear, however, is that after the defeat of the Spanish by the United States, and the negotiation of the Treaty of Paris in 1898, Spain relinquished control of its territories - most importantly, the Philippines. Two days before the treaty's ratification, open conflict erupted between Filipino and American forces in Manila. What would follow was a three year war which led more than 4,200 Americans and over 16,000 Filipino soldiers to their deaths and around 250,000 (if not more) Filipino civilian casualties from famine, violence or disease. ${ }^{180}$ The United States undoubtedly saw value in the acquisition of the Philippines in an attempt to control the archipelago and to keep it out of German or Japanese hands at all costs.

\section{Filipino Displacement and Relocation}

Much like the Anglo-Boer war, the first phase was fought within the first year of the war in the Philippines. Conventional warfare operations fought by both sides lasted from February to November of 1899. The fighting mainly centered in Manila because of its strategic importance though the conflict began to shift more toward the north by November. Filipino nationalists had successfully assisted the Americans in taking control of Manila by isolating Spanish garrisons outside the city and then enveloping Manila.

${ }^{179}$ Linn, Philippine War, 42

${ }^{180}$ Spencer Tucker, The Encyclopedia of the Spanish-American and Philippine-American Wars: A Political, Social, and Military History, Volume /(ABC-CLIO, 2009), accessed February 10, 2013 , http:/books.google.com/books?id $=8 \mathrm{~V} 3 \mathrm{vZxOmHssC \& pg}=\mathrm{PA} 478 \& \mathrm{dq}=$ deaths + in + the + philippine + american + war \&hl $=$ en\&sa $=$ X\&ei $=$ fRUuUYyElvG0QHXn4DABQ\&ved $=0$ CDMQ6AEwAA $\# v=$ onepage $\& q=$ deaths $\% 20 \mathrm{in}^{2} \% 20$ the $\% 20$ philippine $\% 20$ american $\% 20$ war\&f $=$ false 
This position meant that the Americans were in control of Manila Bay after the surrender of the Spanish, leaving them also enveloped by the surrounding Filipino national army. ${ }^{181}$ For months the two armies prepared for a potential clash and in February, the $8^{\text {th }}$ corps of the U.S. Army made short work of the Filipino Army of Liberation. Aguinaldo and his Army of Liberation theoretically should have been able to defeat the American forces simply by way of sheer numbers and civilian population support, allowing the Army of Liberation to attack the Americans at both the front and the rear of their line of defense, striking from within. The Army of Liberation and its military leadership had been ill prepared for an assault and were constantly plagued by poor, short-sighted decision making. ${ }^{182}$

The losses in Manila and the mounting losses throughout the year until November forced the Filipino insurgency further into the interior of the country. It also pressed the issue that they were not suited to fight in open conventional conflict with American forces. The adoption of guerrilla tactics was a decision made by Aguinaldo after the November raid of Tarlac, Aguinaldo's headquarters north of Manila. General MacArthur moved toward Aguinaldo's position and took Tarlac without a fight. This has generally been attributed to the arrival of Brig. Gen. Loyd Wheaton's amphibious landing at San Fabian on the Lingayen Gulf and his 2,500 reinforcement troops that he brought with him. ${ }^{183}$ The geographic location of San Fabian and Wheaton's reinforcements created a choke point north of Manila as Maj. Gen. Henry W. Lawton swept Northeast and

${ }^{181}$ Linn, Philippine War, 42-44

182 Linn, Philippine War, 62

${ }^{183}$ Gregg Jones, Honor in the Dust: Theodore Roosevelt, War in the Philippines, and the Rise and Fall of America's Imperial Dream, (New York: New American Library, 2012), 130

$-78-$ 
MacArthur kept the Filipinos in central Luzon pinned. ${ }^{184}$ Aguinaldo and his forces had no choice but to flee and hope to fight another day. Aguinaldo's main concern had been to escape, which he managed to do. Following this move by American forces and the continued defeats over the last nine months of the Filipino forces, Aguinaldo decided that it was time for a change in strategy. It was clear that the Filipino forces were simply not prepared to fight a conventional war. Therefore, Aguinaldo decreed that from then on, they would utilize their familiarity with the terrain and the local population to blend into their surroundings and continue the fight with irregular tactics, no longer wearing uniforms and fighting a war "without fronts or fixed positions." 185

Military strategy of the United States during the insurgency or guerrilla phase of the war had been shaped from experiences in the Civil War and the Indian Campaigns. Under General Order No. 100, the Regular Army utilized the irregular tactics that had proven useful in the past and were widely accepted. The Order essentially allowed for the pacification of irregular forces by separating them from the civilian population, the separation of noncombatants from armed opponents. Those who continued to resist American forces risked imprisonment, forced removal from their property, or having their homes and their crops burned or destroyed. ${ }^{186}$ The move was intended to restore order and to ensure that violence would be contained and eventually eradicated.

It is important to mention that, due to the 1899 Army Act, American forces in the Philippines consisted of two military organizations; Army Regular forces and the volunteer forces made up of state militias from all of the United States. Army Regulars

184 Brian Linn, The U.S. Army and Counterinsurgency in the Philippine War, 1899-1902, (Chapel Hill: The University of North Carolina Press, 1989), 14

${ }_{185}$ Jones, Honor in the Dust, 130-131

${ }^{186}$ Linn, Philippine War, 9 
were far more disciplined than the irregular volunteers and had a better understanding of military tactics and unit cohesion. The volunteer forces had courage and enthusiasm, yet at times, they proved difficult to control due to restructuring of Army units under different commanders than they had grown accustomed to within their own militia structures back home. ${ }^{187}$

The American forces fought various skirmishes against the guerrillas throughout 1900 , though the plan to pacify the civilian population was not instituted until after McKinley's election in November of 1900. Because of the rapid success in the SpanishAmerican War and the victory over the Liberation Army in Manila, it was believed victory in the Philippines would be achieved much sooner than it was progressing in the winter of 1900. Public pressure in the United States and the fear that "the guerrilla war would become a chronic problem if pacification were not forthcoming," led to the decision to increase military pressure on guerrilla forces. By 1900 , the conditions were right for an offensive against the insurgency in the Philippines. American troop strength was approaching 70,000 , the monsoon season was at its end, allowing greater ease of troop movement, and American forces were well supplied to begin a campaign of pacification. $^{188}$

One aspect of the U.S. Military counterinsurgency approach during this period is worthy of note. In December of 1900, the Army organized a Division of Military Information. The purpose of this organization was to collect any pertinent intelligence that might be useful to the military in countering guerrilla forces. The Division had been

\footnotetext{
${ }^{187}$ Linn, Philippine War, 9-10

188 John Morgan Gates, Schoolbooks and Krags: The United States Army in the Philippines, 18981902, (Westport: Greenwood Press Inc., 1973), 204-205
} 
instructed to "pay agents 'liberally' and give them as much protection as possible." ${ }^{189}$ In Manila alone, special attention was given to the eradication of revolutionary organizations and between November 1, 1900 and February 1, 1901, agents arrested around 600 people, 250 of which were officers of the insurgency. ${ }^{190}$ Contrary to what some might consider an all out insurgency in the region, the opposite is true. According to Linn, "in thirty-four of the seventy-seven provinces (44 percent) the total of military operations between United States troops and supporters of the Philippine Republic was zero; that is, in nearly half of the provinces there was no fighting at all." 191 What this means is that there was not an overwhelming amount of support for the Filipino insurgency, yet they still proved successful against American forces until the U.S. decided it was time to pursue a hard line toward the insurgency and institute the use of spies in major cities and greater pacification efforts.

(The institution of secret organizations within the indigenous community as a counterinsurgency technique was also a tactic utilized by the Ottomans throughout World War I. The organization known as the Teşkilat-1 Mahsusa [Special Organization] was the Special Forces of Enver Paşa. Their purpose was "to cope with what he regarded as twin threats to security of the Ottoman state, namely, indigenous separatist movements and European aggression." 192 Little is known about the organization due to its clandestine nature as well as virtually no scholarship on the organization existing. Philip Stoddard wrote that what is known about the Teşkilat-1 Mahsusa is; it was a secretive and disreputable group engaged in guerrilla warfare, espionage, counter-espionage and

\footnotetext{
${ }^{189}$ Gates, Schoolbooks and Krags, 209

${ }^{190}$ Gates, Schoolbooks and Krags, 208-209

${ }^{191}$ Linn, Philippine War, 185

192 Philip H. Stoddard, "The Ottoman Government and the Arabs, 1911-1918: A Preliminary Study of the Teşkilat-ı Mahsusa" (PhD Diss., Princeton University, 1963), 1
} 
propaganda; the group was not "the proper concern of any department of government" except for the Ministry of War; and that it was "liberally" awarded funding that was "outside the regular war budget." ${ }^{, 93}$ What makes the institution of this organization so fascinating and ultimately relevant to the study of Ottoman counterinsurgency is their creation in general. According to Stoddard's research, sources point to August 5, 1914, as the day the organization was given an official name. He stipulates, however, that Cemal Paşa - Commander of Ottoman forces in Egypt and one of the three leaders of the Empire - referred to the Teşkilat-1 Mahsusa in his memoirs as early as $1913 .{ }^{194}$ If the information based on interviews with former members is true then it indicates that internal security of the Empire from external as well as internal indigenous threats was much greater than many realize).

In 1901, the U.S. truly began placing noticeable pressure on the insurgency and it was clear that it would not last much longer. The Army utilized local native volunteers to hunt down the guerrillas in the field while the Federal party sought to negotiate their surrender. The Army began arresting and deporting the principalia (noble class) that supported the insurgency in a show of force that was meant to be an example to others what the consequences would be if warfare continued. Army units isolated the surrounding mountainous borders to prevent insurgent escape. The Military formed commissions which tried and executed insurgent captives and sanctioned the destruction of crops and the isolation of civilian populations to remove their potential to support the insurgency. ${ }^{195}$

\footnotetext{
${ }^{193}$ Stoddard, "Teșkilat-1 Mahsusa." 49

${ }^{194}$ Stoddard, "Teșkilat-1 Mahsusa." 52

${ }^{195}$ Linn, Counterinsurgency in the Philippine War, 25
} 
American forces were growing weary of guerrilla warfare by September 1901, and the attack on Balangiga was the lynch pin which released the fury of American military reprisal. Balangiga, Samar was the site of a combined attack by guerrillas and townspeople which left 48 Americans dead and 74 wounded. The result is an indication of American resolve to end the war in the Philippines. Linn writes that,

Infuriated by the 'massacre' at Balangiga, frustrated by continued warfare, and outraged at guerrilla terrorism, the Americans ended the Philippine war with vindictive ruthlessness. Brig. Gen. Jacob H. Smith, the commander of the Sixth Separate Brigade, ordered one of his officers to turn Samar into a 'howling wilderness' and to shoot any males over age ten. Brig. Gen. J. Franklin Bell, commanding the Third Separate Brigade in southern Luzon, concentrated most of the populace into guarded zones, where many died of malnutrition and sickness. ${ }^{196}$

The result was the further suffering of civilians, directly through military action or indirectly by the destruction of farms and the loss of livestock. By June of 1902, resulting from the two campaigns under Smith and Bell, the last of the insurgency surrendered.

Smith was eventually court-martialed and five officers were tried for war crimes. ${ }^{197}$

Bell's campaign, however, has since been described as "a masterpiece of counterguerrilla warfare."198

Just as conditions had been in the Anglo-Boer war, camps were, "...overcrowded and suffered from food shortages and sanitation that ranged from poor to appalling." 199 According to Linn, Glen A. May has made the most thorough study of this time period regarding morality and has concluded that due to estimates of malnutrition, substandard

${ }^{196}$ Linn, Counterinsurgency in the Philippine War, 26-27

${ }^{197}$ Linn, Counterinsurgency in the Philippine War, 27

${ }^{198}$ Robert D. Ramsey III, "A Masterpiece of Counterguerrilla Warfare: BG J. Franklin Bell in the Philippines, 1901-1902," Long War Studies Occasional Paper 25 (2007): 12, accessed January 29, 2013, http://usacac.army.mil/cac2/cgsc/carl/download/csipubs/ramseyop25.pdf

${ }^{199}$ Linn, Counterinsurgency in the Philippine War, 155 
sanitation, and disease "...may have cost as many as 11,000 Filipino lives and made the population susceptible to the cholera epidemic of 1902."200 Stuart Miller wrote of Bell's population relocation efforts saying, "The entire population outside of the major cities in Batangas was herded into concentration camps, which were bordered by what Bell called 'dead lines.' Everything outside of the camps was systematically destroyed - humans, crops, food stores, domestic animals, houses, and boats."201

Unfortunately, accurate numbers from this period of history are very hard to come by. Civilian death estimates in the Philippines have been argued as both inflated and understated, with the most conservative estimates at 200,000 and the most extreme estimates at $700,000 .^{202} \mathrm{John}$ Gates argues, however, that due to the public distaste for the war and sensational journalism, as well as statistical manipulation, accurate numbers have been overshadowed by sloppy scholarship. ${ }^{203}$ In fact, Gates argues that the majority of the civilian casualties were the result of a cholera epidemic which infected the islands towards the end of the war and continued after it ended. Gates used the projected population statistics of Filipino birth rates and contrasted those numbers with the 1903 census estimates taken by the Filipino government and concluded that a more accurate number of civilian casualties was actually around $234,000 .^{204}$

Gates attributes the majority of these deaths to cholera and various sources consistently place the number of casualties around 200,000 deaths. This illustrates that regardless of the reasons for civilian collateral resulting from war, the result is the same;

\footnotetext{
${ }^{200}$ Linn, Counterinsurgency in the Philippine War, 155

201 Stuart C. Miller, Benevolent Assimilation: The American Conquest of the Philippines, 18991903, (New Haven: Yale University Press, 1982), 208

202 John M. Gates, "War-Related Deaths in the Philippines, 1898-1902," Pacific Historical Review53 (1984): 367, accessed February 28, 2013, http://www.jstor.org/stable/3639234

${ }^{203}$ Gates, "Deaths in the Philippines," 378

${ }^{204}$ Gates, "Deaths in the Philippines," 376
} 
noncombatants are killed in great numbers especially in counterinsurgency operations. It must also be considered that irregular operations tend to be more costly for the invading or foreign power. It cost the United States an incredible $\$ 400$ million (around $\$ 10$ trillion today) to defeat the Filipino insurgents, which was much more than it had cost to defeat Spain a few years earlier. ${ }^{205}$

Like the efforts of the Anglo-Boer War and the Americans in the Philippines, the Turks were faced with the same issues in relocating large numbers of the population. The logistical difficulties in moving such large numbers of people inevitably results in the catastrophic loss of life, mainly from disease and starvation. Civilian casualties in warfare, no matter the scale, though extremely unfortunate, are inevitable. Downes argued that:

States seek to win the wars they fight quickly and in an economical fashion. States rarely begin wars with a strategy predicated on targeting civilians...In relatively short, bloodless wars...civilian victimization is rare, but when armed conflicts devolve into protracted wars of attrition, the probability mounts that noncombatants will be victimized as a means to reduce costs and avoid defeat. ${ }^{206}$

Downes also argued that, based on data compiled involving all interstate wars between 1816 and 2003, the evidence showed that, "Wars of attrition - conflicts characterized by static, positional warfare, sieges, or counterinsurgency - and wars in which a belligerent intended to conquer and annex its neighbor's land each significantly increased the likelihood of civilian victimization and the number of civilian casualties a state inflicted." 207 Though the conflicts covered in this thesis are limited to the Turks, the

${ }^{205}$ Robert C. Doyle, The Enemy in Our Hands: America's Treatment of Enemy Prisoners of War from the Revolution to the War on Terror, (Lexington: University of Kentucky Press, 2010), 146

${ }^{206}$ Downes, Targeting Civilians, 243

${ }^{207}$ Downes, Targeting Civilians, 243-244 
British and Americans, spanning just over a decade of conflict, this argument further illustrates the fact that civilians often suffer the most in warfare. 


\title{
CHAPTER V
}

\begin{abstract}
ANALYSIS
“Counterinsurgency is not just thinking man's warfare - it is the graduate level of
war. 208
\end{abstract} -Special Forces Officer in Iraq, 2005

The Ottomans did not invent irregular warfare and certainly were not the only great power to encounter insurgency and partisan warfare before or since the First World War. Irregular warfare by definition simply implies that the forces used for fighting are not part of a regular army, making them irregulars. Though, it has often been coupled with the use of unconventional methods making it more of a blanket term to insinuate the use of unregimented tactics. Irregular warfare is particularly complex because it allows the combatants, who have been referred to as partisans, guerrillas, insurgents and even terrorists, to blend into their surroundings by not dawning the military distinction of a uniform. Therefore, they are incredibly difficult to identify, making them equally difficult to isolate from noncombatants.

This also means that whoever the counterinsurgency units may be, they must find a way to combat the threat of unconventional warfare. In some cases, adopting their tactics is a tempting prospect. The United States Army Counterinsurgency Field Manual illustrates this by saying:

${ }^{208}$ The U.S. Army and Marine Corps Counterinsurgency Field Manual, (Chicago: The University of Chicago Press, 2007), 1 
"Counterinsurgency can bring out the worst in the best regular armies. Even when COIN [Counterinsurgency] forces explicitly reject insurgent tactics, they often come to imitate them. In particular, the insurgents' invisibility often tempts counterinsurgents to erase the all-important distinctions between combatants and noncombatants. Historically, this has sometimes been a preferred strategy. $" 209$

In the case of the uniform distinction, however, even if counterinsurgents were to disregard the uniform, they would still be inevitably faced with differences in religion, skin color, language, cultural understanding, territorial awareness and familiarity, and the list goes on and on. Losing the uniform and fighting in civilian clothing is not a wholesale solution. It is a band-aid over a gaping wound. That is to say, there are numerous elements to counterinsurgency operations, like warfare in general, which can be applied to aid a much larger operation.

It goes without saying that the nature of warfare in the twenty-first century continues to shift from large scale conflict to small scale hit and run tactics. The way that great powers worldwide deal with this type of warfare has been carefully crafted through years of experience - trial and error. Perhaps the greatest challenge in counterinsurgency comes from this non military distinction - the stripping away of regular military identification. In such cases, partisans, guerrillas, irregulars or insurgents, rely heavily upon a civilian population in order to supplement their needs as a fighting force. The Cuban revolution of $1953-1959$ is an example of this. In this case, guerrillas fought regular Cuban forces using "Hit and Run" tactics, which essentially entailed attacking the enemy and then dissolving back into the forests and mountains that had become their home as well as their battle ground. Such tactics help in preserving the sustainability of a

\footnotetext{
${ }^{209}$ Counterinsurgency Field Manual, xxxvii
} 
smaller force fighting a larger one. As Che Guevara, field doctor and commander of guerrilla forces in Cuba said:

"Hit and run, wait, lie in ambush, again hit and run, and thus repeatedly, without giving any rest to the enemy. There is in all this, it would appear, a negative quality, an attitude of retreat, of avoiding frontal fights. However, this is consequent upon the general strategy of guerrilla warfare, which is the same in its ultimate end as is any warfare: to win, to annihilate the enemy."210

Irregular units not only employ unconventional tactics but they often have the support of the local people. Another of the more famous revolutionary partisans is Mao Tse Tung, leader of the Chinese Revolution and later Chairman of the People's Republic of China. Throughout the 1930's and 1940's, Mao fought using guerrilla tactics with the intention of ultimately forming a larger regular force in order to return China to the people, famously saying that, "The first law of war is to preserve ourselves and destroy the enemy." 211 Popular support of the people was an absolute necessity to Mao's guerrilla campaign just as it was with Che Guevara and Fidel Castro's revolutionary war in Cuba.

It is easy to condemn the actions of regular forces for using extreme measures in the heat of irregular warfare. The reason for this is simply the heart-wrenching results of civilian involvement, regardless of which side they support. From a fundamental standpoint, however, it is extremely difficult to fight a multi-front war, regardless of its scale. When your enemy is invisible the majority of the time, and not only surrounding your lines of defense but has a presence within them as well, living among you and your troops, the potential for chaos and retribution begins to mount in any theater.

Such was the case in Manila following the end of the Spanish American war and the immediate beginning of another with the Filipino irregulars who had previously been

${ }^{210}$ Emesto "Che" Guevara, Guerrilla Warfare (U.S.:BN Publishing, 2007), 11
211 Mao Tse Tung, On Guerrilla Warfare, (Chicago: University of Illinois Press, 2000), 20 
helping the Americans. Aguinaldo's decision to favor irregular tactics for the remainder of the war was a decision made out of necessity. in the interest of self preservation and continuing the fight against their foreign occupiers. Aguinaldo made it virtually impossible for American forces to discern combatant from noncombatant, apart from the obvious gender and age restrictions in most cases. Because of this, the decision to begin utilizing camps as a means of isolation and as a counterinsurgency tactic is not hard to understand. In the case of the Philippines, especially, the need for containing threats and controlling the pace and location of battles would have been crucial. Due to its geographic location, unique in character, the island format for warfare poses new challenges to the counterinsurgent approach. One challenge would have been the immediacy of establishing security. David Lonsdale wrote:

Modern COIN [counterinsurgency] practice...tends to be regarded less as a form of war and more as a security challenge, with popularity and legitimacy being the key means to achieving the desirable end state. While there is certainly value in the heartsand-minds aspects of COIN doctrine, we must never lose sight of the fact that COIN is still a form of war. In fact, an essential ingredient of COIN is inflicting serious military setback on the insurgents. This not only restricts their ability to undermine security in the contested territory, it also promotes a sense of authority for the local government and their allies. $^{212}$

If Lonsdale is correct in this argument, then dealing critical military blows to the insurgent forces and displaying authority is essential in combating insurgency. What better way to do both than to remove the insurgent's source of support by placing their support base in isolation camps. The insurgents are then more easily separated from the civilians and counterinsurgents have demonstrated to the local population and the government that they are capable of handling the situation, by force if necessary.

${ }^{212}$ Lonsdale, "Strategy," 39 
When the enemy is capable of not only receiving support from a local population for their cause, but also able to hide amongst them without being immediately detected, it is nearly impossible to discern friend from foe, combatant from noncombatant. Therefore, the most logical explanation in the early nineteenth century was to remove the potential threat from theaters of war to a location that can be guarded and monitored in order to minimize the risk of being attacked from within. The human element in irregular warfare and counterinsurgency tactics is ultimately one of the most important aspects when considering the possibilities of success. This was true in the United States following the attack at Pearl Harbor on December 7, 1941. The result of which was the internment of over 100,000 Japanese Americans out of fear that the same internal security threat which was responsible for the attacks could potentially attack again from within the United States. $^{213}$

As it has been demonstrated, the relocation of civilians was also a tactic employed by the British during the Anglo-Boer war of 1899-1902. In this case, prior to the insurgency in the Ottoman Empire during World War I, the British had employed the technique in an attempt to preserve human life and prevent guerrilla support. What followed were the internment of approximately 250,000 people, and the "recorded" deaths of about $45,000 .^{214}$ The British clearly believed that in order to win, the human element must be removed from the equation because of its potential to either support the insurgents or to join their ranks. This mentality has also been demonstrated by the use of

${ }^{213}$ Max Everest-Phillips, "The Pre-War Fear of Japanese Espionage: Its Impact and Legacy", Journal of Contemporary History 42 (2007): 249, accessed April 20, 2012, http://www.jstor.org/stable/30036444

${ }^{214}$ Jenny de Reuck, "Social Suffering and the Politics of Pain: Observations of the Concentration Camps in the Anglo-Boer War 1899-1902", English in Africa 26 (199): 80, accessed April 20, 2012, http://www.jstor.org/stable/40238883 
relocation and internment by the Americans in the Philippines from 1899-1902, resulting in the internment of an unknown number of people and the reported deaths of about 200,000 civilians. $^{215}$

The Ottoman officers (Mekteblis or New Guard), utilized their skills in foreign language by following the developments of other nations prior to World War I - nations such as the United States and Great Britain. They looked to British counterinsurgency during the Boer war for inspiration and ultimately applied such tactics to their encounters with irregular warfare and counterinsurgency. ${ }^{216}$ They had come to be a product of Prussian military strategy because of the Turkish governments' alignment with Germany in World War I.

While the British and the Americans chose to utilize camps to secure civilians and quell insurgency, the Turks used forced relocations. The Ottoman Empire was in dire straits, suffering from fiscal concerns, internal security threats, supply difficulties for their troops and pressure from every angle by the entente powers. Creating camps would have simply not been an option. Building camps for civilian relocation would have cost time and money, two things that the Turks simply could not afford. There was also the threat of a Russian invasion from the east; therefore, choosing a location that would have remained secure would have been difficult in the event of a Russian push west into the empire. There was also certain immediacy to the situation in the east and great concern for solving the problem as quickly as possible. Unlike the British and Americans, the Ottoman counterinsurgency efforts were hindered by foreign support for the insurgents. Though the combat and strategy was fought in similar manner, the Filipinos and the

${ }^{215}$ Doyle, Enemy in Our Hands, 146-147

${ }^{216}$ Uyar and Erickson, A Military History of the Ottomans, 216 
Boers were not backed by active support from a major power. Incidentally, the Armenian revolutionaries were backed by Russia, who provided weapons, funding, training and leadership.

Much like the Ottomans, the Americans and the British used irregular units to handle their insurgency problems. Though, their reasons for this differ. The British decision to use irregular forces was because the British army preferred to use their regular forces elsewhere and saw the Boer rebellion as little more than a skirmish. Tradition would have dictated that the British used their many Indian irregulars to fight the Boers, however, it was decided that this particular conflict should be one comprised of and fought by white men, with two thirds of the army made up of poor Irish and Scots. Even the Boers warned the local Africans not to get involved in the conflict. ${ }^{217}$

The Americans on the other hand, had maintained the regular army as more of a peace keeping force than a blunt instrument of war in 1899 , which had been limited by congress to 28,000 soldiers. The irregular state militias, however, numbered around 115,000 and were used for the majority of Americas fighting. ${ }^{218}$ These were the men who had been called upon to defend America's territories and honor in the Philippines; men eager to prove their worth after hearing countless tales of honor and glory in the Civil War fought by their fathers and grandfathers. As I have previously mentioned, regardless of their enthusiasm, these men ranged from experienced battle formations to inexperienced civilians eager to do their part.

The Ottomans, however, were faced with very distinct challenges which separated them from the British and the Americans. In the Turks case, their insurgency was one

\footnotetext{
${ }^{217}$ Farwell, Anglo-Boer War, 40

${ }^{218}$ Linn, Philippine War, 9-10
} 
fought on their own soil in the eastern part of the empire. Though the trouble was a long way from the capital, the threat was still one bred from within by the revolutionary Armenian community. The Turks, like the British and Americans, relied heavily upon their irregular forces to fight in the east. The reason for this, however, is because they were already entangled in the First World War with the British, Russians and French. The Turks had no choice but to utilize irregular units because their regular units could not be spared. They were being used to support the Germans at the front in Europe. Therefore, the use of irregulars by the Turks was out of necessity and not by choice.

These examples are at least some indication of the tactics used prior to World War I during times of internal security threats. They also indicate that some techniques have not changed, not to mention the fact that such techniques were and have been regularly applied by Western powers since the First World War. The significance of this is that while Western observers have condemned the Ottomans for using internment and civilian displacement, the Ottomans were in fact drawing inspiration from their former British allies. It is also significant because while contemporary and modern Western scholars may argue that the Turks were deliberately attempting to annihilate an ethnic minority in the region, those scholars frequently overlook the fact that their own governments once recognized such techniques as an unfortunate necessity in the early twentieth century. Robert Taber wrote, "Can Guerrilla tactics be employed successfully against Guerrillas? The answer is negative...Indian fighters do not become Indians by taking scalps. A spotted jungle suit does not make a United States Marine a Guerrilla." ${ }^{219}$ The devil is in the details, as is often the case in warfare. Isolating a civilian population from

${ }^{219}$ Taber, War of the Flea, 8 
the possibility of insurgent control through coercion or willful cooperation has become essential in fighting an irregular war. John McCuen wrote:

Since security of the population will be the first objective of the civic action teams and isolation of the guerrillas a primary objective of the territorial forces, both these counter-revolutionary authorities probably will find that regroupment of the population is necessary to accomplish their objectives. Of course, regroupment largely will involve the resettlement of outlying populations which the British successfully employed in Malaya. $^{220}$

There has been a noticeable shift in the way that wars have been fought since the end of World War II. That shift has been one from large scale regular warfare to smaller scale irregular tactics. It is cheaper, more unpredictable, has the potential for foreign support in varying degrees, can last for decades and therefore, is more difficult to eradicate.

Erickson argues that Abdulhamid II and his advisors were aware of the possibility that European forces might intervene on behalf of the Christian separatists in the Balkans during the 1877-78 wars - where the Ottomans began to shape their understanding of counterinsurgency prior to World War I and the rebellion at Van. Even with their military experiences against IMRO (Inner Macedonian Revolutionary Organization) ${ }^{221}$ in the Balkans, the Ottoman hierarchy had consistently passed the responsibility of dealing with counterinsurgency down the chain of command. The system, which was still one of loyalty and patron-client relations under Sultan Abdulhamid II, meant that rather than deal with the problem themselves the unit commanders would often pass the task of

\footnotetext{
${ }^{220}$ John J. McCuen, The Art of Counter-Revolutionary War: The Strategy of Counter-Insurgency, (Harrisburg: Stackpole Books, 1966), 231

${ }^{221}$ IMRO was a blend of militant nationalism and violent insurgency tact. Groups such as IMRO were referred to by the Ottoman Empire as "Komitacis" or members of a secret political organization. Their approach included murder, robbery, extortion, kidnapping and the occasional massacre. (See Erickson, $A$ Military History of the Ottomans, 214)
} 
dealing with counterinsurgency to their officers in the field. ${ }^{222}$ As a result, it was the young officers who had studied European techniques that developed a coherent but unofficial military doctrine for counterinsurgency. Up until the 1890 's, there had been no official or uniform guide for counterinsurgency. It was a system of trial and error applied on the front lines. The result was successful according to Uyar and Erickson saying that, "These unofficial counterinsurgency strategies, tactics, and techniques eventually paid off, and most of the Komitaci [rebel] groups were crushed and lost ground after 1904."223 Therefore, the Ottoman officer corps, responsible for counterinsurgency decisions, had used what they learned from the West in the Balkans, and in turn, applied their experiences from the Balkans to Anatolia.

Compiling all of the relative figures from each military entanglement for the British, the Americans and the Ottomans in each specific case has been examined in this thesis. That is, the relative numbers of government forces and insurgent casualties versus the relative number of civilian casualties of war. What these numbers are meant to illustrate is that while the West condemns the Turks for their counterinsurgency efforts of the First World War, the British and Americans themselves had utilized the same tactics little more than a decade earlier.

The Armenian fifth column posed an eminent threat to Ottoman security and the Ottoman government acted accordingly by removing the threat for the sake of the empire. The Turks were concerned with saving the lives of their Muslim subjects from rebel massacres as well as protecting their investment in the region as a source of tax revenue and internal security from potential threats, mainly Russia. Unlike the Americans in the

\footnotetext{
${ }^{222}$ Uyar and Erickson, A Military History of the Ottomans, 213

${ }^{22.3}$ Uyar and Erickson, A Military History of the Ottomans, 215-216
} 
Philippines and the British in South Africa, the Ottomans stood to lose many more civilians because the war was being waged on their own soil. The fact that they managed to survive in the midst of the greatest war ever fought in history up to that point, fighting an insurgency from within and major powers on two fronts is astounding.

With regard to the importance of the rural population in both insurgent and counterinsurgent operations, the Small Wars Manual states that,

The majority of the people, especially in the rural districts, dislike and fear revolutions, which often involve forced military service for themselves and the destruction of their livestock and their farm produce. However, they may be so accustomed to misgovernment and exploitation that concerted efforts to check disorderly tendencies of certain leaders never occurs to them. It is this mass ignorance and indifference rather than any disposition to turbulence in the nation as a whole, which has prevented the establishment of stable government in many cases. ${ }^{224}$

This is a valid statement with regard to rural populations and their malleability. However, this manual was meant to be a guide to winning small wars through counterinsurgency efforts and is meant to illustrate the importance of civilian support. What this statement also indicates, however, is the malleability of the indigenous forces in the other direction, in support of the insurgents.

${ }^{224}$ Navy \& USMC, Small Wars Manual, sec. 1-13,21 


\section{CHAPTER VI}

\section{CONCLUSION}

"If there is anything new about guerrilla war -- of which Sun Tzu surprisingly anticipates by two thousand years virtually all questions of a military natureit is only in its modern political application. To put it another way, the specifically modern aspect of guerrilla warfare is in its use as a tool of political revolution - the single sure method by which an unarmed population can overcome mechanized armies, or, failing to overcome them, can stalemate them and make them irrelevant.",225

-Robert Taber, War of the Flea, 2002

Until very recently, research into Ottoman counterinsurgency has been virtually nonexistent. If we are to better understand their methods then more research is ultimately necessary. However, based on what we know from the work of Ottoman experts on the First World War, we can safely make a few assumptions about their standards and techniques. It is clear that the Ottoman regular forces had generally operated with the intention of preventing death not instigating it. The Ottoman policy tended to be one of securing the safety of civilians rather than exacting revenge as a primary concern. Though it is also clear that many civilians did in fact suffer at the hands of Turks, both regular and irregular, most of the time the acts of violence were committed by undisciplined irregular troops and civilians who were more concerned with vengeance than conduct. It is understandable that such acts of violence would be at the forefront of a collective irregular consciousness because many of the men chosen to supplement

\footnotetext{
${ }^{225}$ Robert Taber, War of the Flea: The Classic Study of Guerrilla Warfare, (New York: Potomac Books Inc., 2002), 150
} 
Ottoman reinforcements in the region were probably affected directly or indirectly by Armenian violence in the region.

Prior to World War I, the Young Turks of the Committee of Union and Progress had even tried to appease the Armenian Dashnak party by allowing them to carry weapons openly in the streets and to hold public office in the region, most likely to prevent the invasion of Russian forces. The result of which was of course the spreading of revolutionary ideas and the continuance of subversive activity in the Empire, which ultimately led to a Russian invasion of Anatolia anyway. When Ottoman forces could not be used to bring a swift and organized end to the rebellion, irregulars were the responders to the crises and the inevitable occurred.

The assistance provided to the Russians by Armenian spies and scouts cannot be overstated nor should it be forgotten in the pages of history. Although the Armenian rebellion was only a small part of a much larger picture, their efforts were crucial to the invasion of Russian forces. Without Armenian participation, the Russians would not have been afforded all of the advantages that should have been in the Ottomans favor. Knowledge of terrain, troop movements, roads, effective retreat paths, defensive positions and safe passage were known to the Ottomans and not their Russian enemies. With the help of the Armenians, however, the Russians were able to utilize all of these in their invasion. Armenian knowledge of complex terrain made a Russian invasion that much easier in terms of navigating and utilizing geographic complexities with local support. Such aspects are still held in high regard concerning modern warfare and indigenous knowledge of terrain in both insurgent and counterinsurgent operations. ${ }^{226}$ It

${ }^{226}$ U.S. Army and Marine Corps, Counterinsurgency Field Manual, 306 
would be like trying to imagine the Normandy invasion of June 6,1944 without the use of intelligence, disinformation and the $101^{\text {st }}$ airborne division.

Western support of the Armenians' cause also greatly hindered the efforts of the Ottomans to crush the rebellion before it had begun, perhaps saving the lives of thousands in the end. Support groups and fundraisers continued to prevent the Turks from mounting a successful campaign against their internal enemies. In one specific case, a British officer was recruiting an army of refugees in the area of Urumia which was pinned between British and Turkish forces. The idea was to pull together a force large enough to repel the Turks. To help, “indiscreet American missionaries diverted some $\$ 100,000$ in relief funds to support this 'Christian Army.' One of the missionary-relief workers, William Shedd, also the American vice consul at Urumia, seriously compromised the American government by signing in his capacity as vice consul an offer to pay the bills of the Christian army." ${ }^{, 227}$ Contributions such as this were generated by groups who intended to defeat the Muslim heathens and support their Christian brethren in the East. However, in order to facilitate a contribution from Americans, "what was needed was a victim (the Ottoman Christians), a hero (the missionaries), and a villain (the Turks). Turks and Kurds were portrayed as the sole cause of the Christian's plight.,"228

The ABCFM (American Board of Commissioners for Foreign Missions) especially, had a vested interest in the well being of the Christian community in the Ottoman Empire, with special emphasis on the Armenians. Although the ABCFM claimed to strive for the salvation of mankind through the understanding of Christianity

\footnotetext{
${ }^{227}$ Robert L. Daniel, American Philanthropy in the Near East 1820-1960, (Athens: Ohio University Press, 1970), 158

${ }_{228}$ Justin McCarthy, The Turk in America: The Creation of an Enduring Prejudice, (Salt Lake
} City: The University of Utah Press, 2010), 171 
and the western style orthodoxy, there was obviously greater emphasis on educating Ottoman subjects on western practices. This is confirmed by the number of schools built versus the number of churches. Between the time that the missionaries arrived in the Ottoman Empire and the time they were beginning to leave (1850-1913), they had built 450 schools while only building 163 churches. $^{229}$

By drawing conclusions between counterinsurgency tactics before or since the First World War, this thesis demonstrated that justifiable conduct is in the eyes of the beholder. It is necessary to recognize that the Turks were not monsters but pragmatists faced with a nation in disarray and the destruction of their empire. Not to mention an uncertain fate for their Muslim subjects should they be defeated, a fate which had previously been proven worse than death and exile in the Balkans. Not only were their inspirations, and indeed some of their military tactics derived from Western military strategy prior to the war, but the Western powers of the twentieth century continued to operate under the same principles after World War I. Napoleon Bonaparte wrote that "God is on the side with the best artillery." The sarne is true in the recognition of suffering during wartime. The condemnation of atrocities is generally heard from those with the loudest microphone or the boldest pen stroke.

In his account of world history, H.G. Wells wrote of the Greco-Turkish war of 1919-1922 saying, "The vitality of the Turk in this phase [post World War I recovery] was remarkable. He was not only driving back the attacking Greek, but he was, after his age-long tradition, massacring Armenians, and he was driving the French out of

\footnotetext{
${ }^{229}$ Cagri Erhan, "Ottoman Official Attitudes Towards American Missionaries," Yale Center for International and Area Studies. http://www.yale.edu/macmillan/cmes/publications.html (accessed September 30, 2011). 326
} 
Cilicia." ${ }^{230}$ Unfounded history written in such a suggestive manor is damaging to the best obtainable versions of the truth, the very purpose of writing history itself. Western historians to follow, in turn, draw inspiration from their predecessors and perpetuate myths of the "Terrible Turk" and his Armenian blood lust.

The counterinsurgency techniques of the Ottomans have remained under Western scrutiny with regard to forced relocation. However, against all odds, the Turks managed to maintain regional security and integrity after losing the greatest war the world had yet seen. The problem with counterinsurgency operations is that even with doctrinal theory and application, it is ultimately meant to be a bulleted remedy to a military problem, wrapped in a nice, neat package containing solutions to rapidly evolving tactics. Unlike regular warfare, counterinsurgency is a process which is rarely afforded a standard solution. Michael Schafer argues that,

In fact, counterinsurgency doctrine obscures rather than illuminates critical distinctions among insurgency-threatened governments and the prospects for aid to them. As a result, past counterinsurgency operations were undertaken blind, while today the United States still lacks an ability to read the auguries for victory accurately. ${ }^{231}$

If nothing else, this argument highlights the need to adapt in irregular warfare and

illustrates the many challenges faced regarding counterinsurgency operations even in the twenty-first century.

Byron Farwell wrote of the Boer war saying:

The methods by which guerrillas are overcome are, for humane men, unpalatable because they involve making war upon entire populations, upon those who in orthodox warfare are considered noncombatants. But as guerrillas are dependent upon the noncombatant populations for supplies, information, and other necessities, and the passive, if not active, support of the people among whom they move is essential, these

${ }^{230}$ H.G. Wells, The Outline of History, (New York: Garden City Books, 1949), 1122

${ }^{231}$ Michael D. Shafer, "The Unlearned Lessons of Counterinsurgency," Political Science Quarterly 103 (1988): 57, accessed February 2. 2013, http://www.jstor.org/stable/2151141 
people - housewives who count the men and guns in the passing column, small boys who have seen the hiding soldiers in the their ambush, old men who know forgotten paths become a danger to the counter-guerrilla forces and minatory action is taken against them. So terrorism becomes a standard feature of guerrilla wars.

Middle ground regarding counterinsurgency, irregular, guerrilla or whatever term you prefer to use, simply does not exist. Notions of man's humanity to his fellow man are often forgotten in all warfare when his way of life has been threatened. This is true of both the aggressor and the defender in virtually any conflict. Current counterinsurgency doctrine of the west strives for a more amiable solution. The fact remains, however, that in the context of the time, such measures were viewed as an unfortunate necessity in irregular warfare.

Sean McMeekin wrote that, "Turkish historians, while acknowledging that thousands of innocents died in the course of the relocations, have tended to emphasize alleged Armenian treachery at Sarıamış, Van, Cilicia and elsewhere, which convinced the CUP government it had a fifth column on its hands." ${ }^{, 232}$ This thesis has illustrated that the threat was in fact very real, and the effectiveness of the Armenian revolutionaries was detrimental to Ottoman security in the East and essential to the Russian invasion of Anatolia. McMeekin goes on to admit that the security threat was indeed real, yet, it was "overblown" and the Turks management of the forced relocations was "murderous." 233 Unfortunately, history written in such a way denotes the logistical challenges of conducting counterinsurgency operations while also fighting a multi-front war. Perhaps one of the greatest questions which remains unanswered in this thesis is; were the Turks justified in their actions? Militarily, it is arguable that the Turks were

\footnotetext{
${ }^{232}$ Sean McMeekin, The Berlin-Baghdad Express: The Ottoman Empire and Germany's Bid for World Power, (Cambridge: The Belknap Press of Harvard University Press, 2010), 242

${ }_{233}$ McMeekin, Berlin-Baghdad Express, 251
} 
justified simply by examining the probability of annihilation. They had very little time to act and virtually no money to speak of in order to build camps or shelter in eastern Anatolia to house the refugee populations - both Muslim and Armenian. However, even if the Turks had the money and time for such projects, the camps would have to be built in an area far from the front toward the interior of the country, far enough away from the battlefield to ensure their safety. Therefore, the refugees would have had to make a long and arduous trek across county anyway. Also, as previous chapters have illustrated, as well as a number of scholars, the great killer of men at the time was epidemic; cholera, typhoid, frostbite, starvation etcetera. Disease and starvation killed most of the interned in the camps of South Africa and also the majority of interned in the Philippines both during and after the war.

Were the Turks actions of the First World War morally justifiable in the forced relocations of thousands of civilians? Obviously not, however, it is important to remember that perceived necessity often dictates and even usurps morality in times of crisis. That is not to say that it is justified, yet it is evident that the Turks are not the only major power to make such a decision in the interest of security and stability. This was evident in the actions of the Americans in the Philippines and the British in South Africa as well. The only glaring difference between these examples of Western and Ottoman counterinsurgency is that the West was not directly threatened by insurgency on their own soil in the midst of a major war on multiple fronts. In its historical context, from a counterinsurgency standpoint, such decisions to move large numbers of civilians in the interest of security were a perfectly acceptable solution at that time. Such options are no longer viable in modern counterinsurgency operations. 
This thesis has demonstrated that, from the Ottoman perspective, there was a genuine belief in an imminent threat from the insurgent Armenian community. Countless Ottoman documents have shown that, based on intelligence, the Ottomans recognized the Armenian will to create their own state in the Ottornan Empire. Though they sided with Russia in their common hatred toward the Ottoman Empire, the Armenians were willing to use the avenue of Russian support as a vehicle for attaining independence. It is also clear, based on Ottoman documents, that the Ottoman government perceived a real threat to the Muslim population of Eastern Anatolia, and that their decision to forcibly relocate Armenians was one also made in the interest of protecting its Muslim subjects from Armenian reprisal.

This thesis has demonstrated the need for future researchers to recognize the challenges that counterinsurgency operators face, both in the past and the present. It is essential to remember that warfare, like history itself, is a sprawling and confused network of information that at times remains an enigma. Historians have a responsibility to strive for the best obtainable versions of the truth, remembering to always view research from a variety of angles so that students of history can make informed decisions. It does one well to remember that there will and have always been innumerable variables in the examination of history, and that the angle from which we view it should always be obtuse. 


\section{REFERENCES}

Ahern, Thomas L. Jr., Vietnam Declassified: The CIA and Counterinsurgency, Lexington: University of Kentucky Press, 2010.

Allen, W.E.D, and Paul Muratoff, Caucasian Battlefields: A History of the Wars on the Turco-Caucasian Border 1828-192. Cambridge: Cambridge University Press, 1953.

Beckett, Ian F. W.. Modern Insurgencies and Counter-Insurgencies: Guerillas and their opponents since 1750. London: Routledge, 2001.

Constantine, Peter. ed. \& trans., The Essential Writings of Machiavelli. New York: The Modern Library, 2007.

Daniel, Robert L.. American Philanthropy in the Near East 1820-1960. Athens: Ohio University Press, 1970.

De Reuck, Jenny. "Social Suffering and the Politics of Pain: Observations of the Concentration Camps in the Anglo-Boer War 1899-1902", English in Africa 26 (199): 80, accessed April 20, 2012, http://www.jstor.org/stable/40238883

Department of the Army. U.S. Army Guerrilla Warfare Handbook. New York: Skyhorse Publishing Inc., 2009.

Department of the Navy and the USMC, Small Wars Manual. Washington: The United States Government Printing Office, 1940.

Downes, Alexander B.. Targeting Civilians in War. Ithaca: Cornell University Press, 2008.

Doyle, Robert C.. The Enemy in Our Hands: America's Treatment of Enemy Prisoners of War from the Revolution to the War on Terror. Lexington: University of Kentucky Press, 2010.

Ellis, John. From the Barrel of a Gun: A History of Guerrilla, Revolutionary and Counter-Insurgency Warfare, From the Romans to the Present. London: Greenhill Books, 1995. 
Erhan, Cagri. "Ottoman Official Attitudes Towards American Missionaries." Yale Center for International and Area Studies.

http://www.yale.edu/macmillan/cmes/publications.html. Accessed September 30, 2011.

Erickson, Edward J.. Ordered to Die: A History of the Ottoman Army in the First World War. London: Greenwood Press, 2001.

Everest-Phillips, Max. "The Pre-War Fear of Japanese Espionage: Its Impact and Legacy", Journal of Contemporary History 42 (2007): 249. Accessed April 20, 2012 , http://www.jstor.org/stable/30036444

Farwell, Byron. The Great Anglo-Boer War. New York: Harper and Row Publishers, 1976.

Galula, David. Counterinsurgency Warfare: Theory and Practice. London: Praeger Security International, 2006.

Gates, John Morgan. "War-Related Deaths in the Philippines, 1898-1902." Pacific Historical Review53 (1984): 367-378. Accessed February 28, 2013. http://www.jstor.org/stable/3639234.

Gates, John Morgan. Schoolbooks and Krags: The United States Army in the Philippines, 1898-1902. Westport: Greenwood Press Inc., 1973.

Guevara, Ernesto “Che”. Guerrilla Warfare. U.S.:BN Publishing, 2007.

Halaçoğlu, Yusuf. The Story of 1915: What Happened to the Ottoman Armenians?. Ankara: The Turkish Historical Society, 2008.

Jones, Gregg. Honor in the Dust: Theodore Roosevelt, War in the Philippines, and the Rise and Fall of America's Imperial Dream. New York: New American Library, 2012.

Kiras, James, "Irregular Warfare." In Understanding Modern Warfare, edited by James Kiras, David J. Lonsdale, David Jordan, Ian Speller, Christopher Tuck and C. Dale Walton, 225-276. New York: Cambridge University Press, 2008

Le May, G. H. L.. British Supremacy in South Africa 1899-1907. Oxford: Clarendon Press, 1965.

Linn, Brian M.. The Philippine War:1899-1902. Lawrence: University of Kansas Press, 2000.

Linn, Brian M.. The U.S. Army and Counterinsurgency in the Philippine War, 1899-1902. Chapel Hill: The University of North Carolina Press, 1989. 
Lonsdale, David J., "Strategy." In Understanding Modern Warfare, edited by David J. Lonsdale, David Jordan, James D. Kiras, Ian Speller, Christopher Tuck and C. Dale Walton, 15-58. New York: Cambridge University Press, 2008.

Marques, Patrick D. "Guerrilla Warfare Tactics in Urban Environments." M.A. Thesis, US Army Command and General Staff College, 2003. 23-31

McCarthy, Justin, Esat Arslan, Cemalettin Taşkıran, and Ömer Turan. The Armenian Rebellion at Van. Salt Lake City: The University of Utah Press, 2006.

McCarthy, Justin. "The Destruction of Ottoman Erzurum (Osmanlı Erzurum Tahribatı)". Erzurum: Ankara Üniversitesi, 2002. (Authors Manuscript Copy)

McCarthy, Justin. Death and Exile: The Ethnic Cleansing of Ottoman Muslims 1821-1922. Boston: Darwin Publishers, 1995.

McCarthy, Justin. Population History of the Middle East and the Balkans. Istanbul: The Isis Press, 2002.

McCarthy, Justin. The Turk in America: The Creation of an Enduring Prejudice. Salt Lake City: The University of Utah Press, 2010.

McCuen, John J.. The Art of Counter-Revolutionary War: The Strategy of Counter-Insurgency. Harrisburg: Stackpole Books, 1966.

McMeekin, Sean. The Berlin-Baghdad Express: The Ottoman Empire and Germany's Bid for World Power. Cambridge: The Belknap Press of Harvard University Press, 2010.

Miller, Stuart C. Benevolent Assimilation: The American Conquest of the Philippines, 1899-1903. New Haven: Yale University Press, 1982.

Meredith, Martin. Diamonds, Gold, and War: The British, the Boers and the Making of South Africa. New York: Public Affairs, 2007.

Oke, Mim Kemal. The Armenian Question 1914-1923. Oxford: University Printing House, 1988.

O'Neill, Bard E. Insurgency and Terrorism: From Revolution to Apocalypse. Washington D.C.: Potomac Books Inc., 2005.

Ramsey, Robert D. III. "A Masterpiece of Counterguerrilla Warfare: BG J. Franklin Bell in the Philippines, 1901-1902." Long War Studies Occasional Paper 25 (2007): 8-24 accessed January 29, 2013.

http://usacac.army.mil/cac2/cgsc/carl/download/csipubs/ramseyop25.pdf 
Savage, Charlie. "An Iraqi Massacre, a Light Sentence and a Question of Military Justice." The New York Times, January 27, 2012. Accessed February 11, 2013. http://www.nytimes.com/2012/01/28/us/an-iraqi-massacre-a-light-sentence-and-aquestion-of-military-justice.html? $\mathrm{r}=0$

Shafer, Michael D.. "The Unlearned Lessons of Counterinsurgency." Political Science Quarterly 103 (1988): 57-80. Accessed February 2, 2013. http://www.jstor.org/stable/2151141.

Sonyel, Salahi. The Great War and the Tragedy of Anatolia: Turks and Armenians in the Maelstrom of Major Powers. Ankara: Turkish Historical Society Printing House, 2000.

Spear, Joanna. "Counterinsurgency." in Security Studies: An Introduction, edited by Paul D. Williams. New York: Taylor \& Francis, 2008.

Stoddard, Philip H.. "The Ottoman Government and the Arabs, 1911-1918: A Preliminary Study of the Teşkilat-1 Mahsusa." (PhD Diss., Princeton University, 1963).

Taber, Robert. War of the Flea: The Classic Study of Guerrilla Warfare. New York: Potomac Books Incorporated, 2002.

The U.S. Army and Marine Corps Counterinsurgency Field Manual. Chicago: The University of Chicago Press, 2007.

Tse-tung, Mao. On Guerrilla Warfare. Translated by Samuel B. Griffith II. Chicago: University of Illinois Press, 2000.

Tucker, Spencer. The Encyclopedia of the Spanish-American and PhilippineAmerican Wars: A Political, Social, and Military History. Volume 1(ABC-CLIO, 2009), accessed February 10, 2013, http://books.google.com/books?id=8V3vZxOmHssC\&pg $=$ PA478\&dq $=$ deaths + in + the + ph ilippine + american + war $\& h \mathrm{~h}=$ en $\& \mathrm{sa}=\mathrm{X} \& \mathrm{ei}=\mathrm{fRUuU}$ YyEIvG0QHXn4DABQ\&ved=0CDMQ6AEwAA\#v=onepage\&q=deaths $\% 20 \mathrm{in} \% 20$ the $\% 20$ philip pine $\% 20$ american $\% 20$ war \&f $=$ false

Turkey. General Staff Command. Arşiv Belgeleriyle şiirlerini Faaliyetleri 19141918 Cilt I. Ankara: Genel Kurmay Basım Evi, 2005.

Turkey. General Staff Command. Arşiv Belgeleriyle şiirlerini Faaliyetleri 19141918 Cilt 2. Ankara: Genel Kurmay Basım Evi, 2005.

Turkish Republic Prime Ministry. Armenians in Ottoman Documents 1915-1920. Ankara: Directorate of Ottoman Archives, 1995. 
Tzu, Sun. The Art of War. Translated by The Denma Translation Group. Boston: Shambala, 2002.

United States Marine Corps. Guidebook for Marines. Quantico: Marine Corps Association, 2001.

Uyar, Mesut, and Edward J. Erickson, A Military History of the Ottomans: From Osman to Ataturk. Santa Barbara: ABC CLIO, 2009.

Wells, H.G.. The Outline of History. New York: Garden City Books, 1949. 


\section{CURRICULUM VITAE}

NAME: Nicholas Allen Warndorf

ADDRESS: 709 South Third Street \#234

Louisville, KY 40202

DOB: $\quad$ Erlanger, Kentucky - September 23, 1987

EDUCATION

\& TRAINING: $\quad$ B.S., History

Northern Kentucky University

2005-2011 